\title{
Hogyan árazza a piac a felelős és fenntartható befektetéseket?*
}

\author{
Timár Barnabás
}

Tanulmányomban azt vizsgálom, hogy igazolható-e az a hipotézis, mely szerint a befektetők szemszögéböl pénzügyileg jövedelmezőbb lehet a felelős, fenntartható vállalatokba történő befektetés, azaz nagyobb profit érhető el, mint az ezeket a szempontokat mellőző cégekkel. További feltételezésem, hogy ez a profit növelhető, ha különböző szükitéseket vagy relatív pontszámokat alkalmazok. Hipotéziseimet a New York-i tőzsde adatain empirikusan vizsgáltam, befektetési stratégiákon (portfólió képzés) és részvényszinten (regresszió) is. A teszteket a teljes piacon, részletes iparági bontásban és csoportosításban egyaránt elvégeztem. A vizsgált mutatókat (ESG, ENV) magukban és relatív megközelítéssel, több időhorizonton is teszteltem. A vizsgálatok nagy részénél nem szignifikáns eredményeket kaptam, néhány iparág esetében látható gyengébb negativ hatás, illetve a regressziók esetében kaptam szignifikáns, de elenyésző gazdasági jelentőséggel bíró koefficienseket. Az időbeni megbontásból látható az ESG és ENV növekvő jelentősége, de a későbbi idősor esetében sem tekinthetö szignifikánsnak. Az eredmények arra utalnak, hogy a vizsgált szempontokat a piac egyelöre nem árazza be, így hipotéziseim nem igazolódtak. Ennek oka a Greenwashing-jelenség, vagy az USA fejlett piaca lehet.

Journal of Economic Literature (JEL) kódok: G17, G32, G41

Kulcsszavak: Fama-French, ESG, ENV, környezetvédelem, faktor, fenntarthatóság, hozam, USA, tőzsde

\section{Bevezetés}

A felelős és fenntartható befektetés napjainkban egyre fontosabb és népszerübb (Kuzmina - Lindemane 2017). A növekedés és a profit már nem zárja ki a környezetvédelmet (Németh-Durkó 2019). A vállalatok vezetése is felismerte a környezettudatosság és a fenntarthatóság fontosságát (Bank 2018, Ransburg - Vágási 2011). Ennek mérésére az ESG-pontszámot szokás alkalmazni (Townsend 2020).

\footnotetext{
* A jelen kiadványban megjelenő írások a szerzők nézeteit tartalmazzák, ami nem feltétlenül egyezik a Magyar Nemzeti Bank hivatalos álláspontjával.

Timár Barnabás a Budapesti Corvinus Egyetem alapszakos hallgatója.

E-mail: barnabas.timar@stud.uni-corvinus.hu

A tanulmány első verziója a Budapesti Corvinus Egyetem MNB Intézet és a Nemzetközi, Politikai és Regionális tanulmányok Intézet által szervezett 'Zöld pénzügyek' kutatási versenyre készült, ahol 1. helyezést ért el. 
Az ESG három pillérből tevődik össze: a környezet és védelme (environmental, a továbbiakban ENV), a szociális (social), valamint a vállalatirányítással kapcsolatos kritériumok (governance). A pontszám a kritériumoknak való megfelelést méri, így alkalmazható a fenntarthatóság mérésére. Tanulmányom során az ESG-t és ENV-t a felelős és fenntartható befektetések megfelelő közelítésének tekintem, mivel ezek a mérőszámok alapvetően erre a célra készültek, de természetesen ennek a megközelítésnek is vannak hiányosságai és megfogalmazható vele szemben kritika is (Id. Kotsantonis - Serafeim 2019). Ennek ellenére, követve a nemzetközi irodalmat, én is ezt az értéket tekintem irányadónak (Auer - Schuhmacher 2016). A növekvő fontosság jól látható abból is, hogy míg az 1990-es években alig néhány vállalat közölte az ESG-pontszámát, mára már sok ezer vállalat teszi ezt rendszeresen (Kotsantonis et al. 2016). A felelős viselkedés számos előnnyel járhat egy adott vállalat számára, például versenyelőnyt jelenthet a munkaerő-, termék- vagy tőkepiacon (Kotsantonis et al. 2016). Számos tanulmány vizsgálja az ESG-n keresztül a felelős vezetés hatását az adott vállalatra. Buallay (2019) azt találja, hogy a mutató hatással lehet a cég teljesítményére, a ROE²-ra és a ROA³-ra is. Deák és Hajdu (2011) is hasonló eredményeket kap, miszerint azokban a vállalkozásokban, ahol a környezeti teljesítményt kedvezően ítélik meg, magasabb a ROE. Gillan et al. (2010) a hatékonyság növekedéséről szolgál bizonyítékkal, Kotsantonis et al. (2016) pedig alacsonyabb tőkeköltségről számol be a magasabb ESG-vel rendelkező vállalatok esetében. Ezek alapján azt mondhatjuk, hogy a vállalat számára pénzügyi szempontból is érdemes a fenntartható működésre törekedni.

A kérdés egy másik oldala, hogy a befektetők szemszögéből pénzügyileg jövedelmező lehet-e a felelős és fenntartható vállalatokba történő befektetés? Tanulmányom erre a kérdésre fókuszál, és erre keresi a választ. A hozamok magyarázata már soksok éve foglalkoztatja a pénzügyi területen kutatókat, számos elmélet látott már napvilágot. Az 1960-as évek óta a legismertebb elmélet a tőkepiaci árfolyamok modellje (Capital Asset Pricing Model, CAPM). Ez az elmélet átfogó modellt kínál a hozamok alakulásának magyarázatára. Azonban számos kritika érte már, és többen bizonyították, hogy a gyakorlatban nem müködik megfelelően (Berlinger - Walter 1999; Fama - French 1996; Lai - Stohs 2015; Fernandez 2015). Ennek hatására jöttek létre a faktormodellek, melyek egyéb tényezők segítségével igyekeznek a várható hozamok pontosabb előrejelzésére. A faktormodellek megalkotójának Fama és French (1992) tekinthető, de előtte mások is foglalkoztak hasonló (piaci anomáliákkal foglalkozó) vizsgálatokkal. A faktormodellek már statisztikailag szignifikáns módon képesek a hozamok magyarázatára, és napjainkra elfogadottnak tekinthetők (Fain - Naffa 2019). Alapnak Carhart (1997) négyfaktoros modellje tekinthető,

\footnotetext{
${ }^{1}$ Részletesebben lásd az 1.1. alfejezetet.

2 return on equity = tőkearányos megtérülés

${ }^{3}$ return on assets $=$ eszközarányos nyereség
} 
melyben a CAPM bétáját, a piaci méretet, a könyv szerinti és a piaci érték hányadosát, valamint a momentumot használja a hozamok magyarázatára.

Tanulmányomban részletesen vizsgálom a felelős és fenntartható menedzsment (ESG és ENV) kapcsolatát a jövőbeli részvényhozamokkal. Az ESG-t és az ENV-t többek között egy lehetséges faktorként tesztelem a hozamok előrejelzésére, ezzel vizsgálva a stratégia jövedelmezőségét. Az alap feltételezés, hogy a befektetők értékesebbnek találják, díjazzák a felelős és fenntartható menedzsmentet, és ez tükröződik a részvények árfolyamában, ezáltal a hozamokban is (Hassel-Semenova 2013). Egy további lehetőség az is, hogy a piac a kiugró pontszámokra érzékeny, tehát például a különösen szennyező vállalatokat bünteti kedvezőtlen árazással. A kapcsolat vizsgálatához használt egyik módszer egy olyan kereskedési stratégia elemzése, mely az alacsony pontszámmal rendelkező részvényeket eladja, míg a magasakat megveszi, ezáltal átfogó képet ad, bármilyen kapcsolat is legyen az ESG és a hozamok között. Ezenfelül Fama-MacBeth-regresszióval (Id. Fama - MacBeth 1973) is vizsgálom a kapcsolatot, több tényezőre kontrollálva. Az elemzést a New York-i tőzsde részvényein végzem, vizsgálom a teljes piacot, és részletes iparági bontást, valamint iparági csoportosítást is alkalmazok. A teszteket elvégzem mind ESG-re, mind pedig külön az ESG környezeti komponensére (ENV), ezenfelül pedig újfajta megközelítést is alkalmazok a relatív ESG, valamit a relatív ENV tesztelésével, ami az iparági átlagtól vett eltérést vizsgálja. Feltett hipotézisem, hogy a felelős és fenntartható szempontokat figyelembe vevő menedzsmenttel rendelkező vállalatokba történő befektetéssel nagyobb profit érhető el, mint az ezeket a szempontokat mellőző cégekkel. További hipotézisem, hogy ez a profit növelhető, ha különböző szúkítéseket vagy relatív pontszámokat alkalmazok.

A meglévő irodalom megosztott, számos tanulmány készült ezen a területen különböző eredményekkel. Verheyden et al. (2016) pozitív kapcsolatot talál, ha a portfólióból elhagyja a legrosszabb pontszámmal rendelkező cégeket (az összes 10 százalékát), azonban a pozitív hatást csak a kockázattal korrigált hozamok esetében tudja kimutatni. Landi - Sciarelli (2019) kutatása Olaszországot vizsgálja, és nem talál pozitív kapcsolatot, ha a portfólióképzés során különböző ESG-kritériumokat alkalmaz. Torre et al. (2020) nem talál kapcsolatot az ESG és a jelentős európai részvények hozamai között, többféle ESG-indikátort alkalmazva sem. Maiti (2020) arra a következtetésre jut, hogy az ESG-t használva a Fama - French (1992) háromfaktoros modellnél hatékonyabbat képes építeni. Itt azonban inkább a kockázat és kezelése a hangsúlyos, az eredmények ebben az esetben is a kockázattal súlyozott hozamra igazak. Halldórsdóttir (2020) az eseményelemzés módszertanával vizsgálja az ESG és a hozamok kapcsolatát a Covid-19 tekintetében. Azt a következtetést vonja le, hogy az ESG-nek nincs hatása az Amerikai Egyesült Államok piacán. Jain et al. (2019) a világ számos nagyobb piacát vizsgálja, arra a kérdésre keresve a választ, hogy fenntarthatósági indikátorok segítségével elérhető-e magasabb hozam. 
Megállapítása, hogy a hagyományos, valamint a felelős és fenntartható módszerek használata hasonló hozamhoz vezet. Kumar et al. (2016) szerint az ESG-nek ugyan a hozamokra nem biztos, hogy van hatása, viszont a jó pontszámmal rendelkező cégek árfolyamának szignifikánsan kisebb a volatilitása. Khan (2019) tanulmánya olyan modellt épít, mely az ESG-pontszámot is figyelembe veszi a befektetés során, és konklúziója, hogy lehet az ESG-ben érték a befektetők számára. Sahut és Pasquini-Descomps (2015) tanulmányukban az Amerikai Egyesült Államokat, Svájcot és az Egyesült Királyságot vizsgálják a 2007-2011 közötti időszakban, és csak az Egyesült Királyság esetében találják szignifikánsnak az ESG-t. Auer - Schuhmacher (2016) globális vizsgálatot végez iparági szinten, melyben az amerikai egyesült államokbeli és az ázsiai-csendes óceáni piacokon nem talál eltérést a piaci és az ESG-portfólió teljesítménye között. Európa esetében viszont látható, hogy a befektetők felárat fizetnek a felelős befektetésekért. Kumar (2019) tanulmányában arról számol be, hogy az ESG nem rendelkezik plusz információval a faktormodellekhez képest az európai piac esetében. Aouadi - Marsat (2018) nemzetközi szinten vizsgálja az ESG hatását a vállalatok piaci értékére 2002 és 2011 között. Következtetésük, hogy nincs direkt hatása arra. Buallay (2019) amerikai bankok esetében vizsgálja az ESG hatását 2007 és 2016 között, és szignifikáns hatást talál a piaci teljesítményre. Maiti (2020) tanulmánya alkalmas kockázatkezelési faktornak találja az ESG-t. Gloßner (2017) és Landi - Sciarelli (2019) negatív kapcsolatot mutat ki. A kérdéskörrel befektetési alapok esetében is foglalkoznak, és itt általában kimutatható az ESG-alapok jobb teljesítménye (Wimmer 2013; Henke 2016; Bóta 2014). Fontos továbbá Halbritter - Dorfleitner (2015) következtetése, miszerint számos tényező befolyásolhatja az eredményeket, például az időhorizont, az iparág, a pontszámszámítási módszer és az, hogy az adatok milyen adatbázisból származnak. Azokon a területeken, ahol a szakirodalomban nincs konszenzus, mindenképpen érdemes további kutatásokat végezni. Jelen tanulmány hozzáadott értékül a meglévő irodalomhoz egy részletesebb, teljeskörű vizsgálat eredményét mutatja be az amerikai piacon azáltal, hogy hosszabb időtávot, több időszakot vizsgál, illetve számos megkötést és szúkítést alkalmaz az eredmények elemzése és robusztusságának biztosítása érdekében.

\subsection{Felelős és fenntartható befektetések mérőszáma (ESG és ENV)}

A felelős és fenntartható befektetésnek napjainkra már számos mérőszáma létezik. Közülük az ESG az egyik leghatékonyabb és legelterjedtebb (Talan - Sharma 2019). Az ESG-mutató, ahogyan már említettem, három pillérből tevődik össze: a környezet és védelme, a szociális kritériumok, valamint a vállalatirányítással kapcsolatos kritériumok. A három pillér önállóan, egymagában is értelmezhető, de szokás együttesen ESG-ként vizsgálni, így átfogó képet kaphatunk arról, hogy az adott vállalat mennyire követi az elvárt irányelveket, és a befektetés mennyire tekinthető fenntarthatónak (Ribando - Bonne 2010). A környezetvédelmi pillér magában foglalja a vállalat természethez való viszonyát, az energiafelhasználását, hulladékgazdálkodását, szennyezőanyag-kibocsátását, a megújulóenergia-felhasználását és az 
esetleges környezetvédelmi kockázatokat. Így az ENV pillér hatékony mérőszáma a fenntartható befektetésnek (Van Duuren et al. 2016). A szociális kritériumok azt vizsgálják, hogy a vállalat milyen kapcsolatban áll az alkalmazottakkal, a beszállítókkal, a vevőkkel és a kapcsolódó közösségekkel. A vállalatirányítás pillér azt vizsgálja, hogy a menedzsment valóban a részvényesek érdekét képviseli-e, hogyan funkcionál az igazgatóság (elegendően sokszínű, független és tagjai kellő tapasztalattal rendelkeznek-e), megfelelő belső szabályozással rendelkezik-e a vállalat az illegális tevékenységek és csalások elkerüléséhez.

Az ESG egyre népszerúbb mutató a befektetők körében is a vállalatok megítélésére, egyre több befektetési alap és brókercég kínál ESG alapú befektetést. Egy a US SIF Foundation (2018) által készített tanulmány azt mutatja, hogy a befektetők az USA-ban közel 12 trillió dollárt tartanak ESG alapú befektetésekben, és ez a szám dinamikusan növekszik. Az ESG-mutató többféleképpen is számítható és különböző skálákon is mérhető. Tanulmányomban a Thomson Reuters által kiadott 100-as skálát (Ribando - Bonne 2010) használom, mivel ez az egyik legelterjedtebb, és biztosítja a statisztikai módszerek alkalmazásához szükséges árnyaltságot ( $L i-$ Polychronopoulos 2020). A vizsgált piacon is ez áll rendelkezésre a legtöbb vállalat esetében. További előnye, hogy ugyanabból az adatbázisból elérhető, mint az általam használt többi adat, így csökkentve az adathibák lehetőségét. A konkrét pontszámokon kívül lehetséges egyéb kritériumok és elvárások megfogalmazása is, például a szén- vagy a hadiipari kitettség, vagy a munkahelyi diszkriminációval kapcsolatos botrányokban szereplő vállalatok elkerülése. Ez segíthet a valóban felelős vállalatok megtalálásában és a fenntartható befektetési döntések meghozatalában, de ezektől most eltekintek. Az ESG definíciójából adódóan kiváló mérőszáma a felelős és fenntartható menedzsmentnek, így megfelelő az elvégezni kívánt vizsgálatokhoz. A klímaváltozás és más tényezők miatt egyre nagyobb jelentősége van a környezetvédelemnek és a kifejezetten zöld befektetéseknek is, ezért a tanulmányban nemcsak az ESG-t, hanem növekvő jelentősége miatt, önmagában is vizsgálom az ENV pillért.

\section{Az alkalmazott módszertan}

A tanulmány során bemutatott vizsgálatok alapját az irodalomban az új faktorok teszteléséhez alkalmazott módszertan (Mérő et al. 2019) nyújtja. Két fontos vizsgálati eszközt alkalmazok, a befektetési stratégiák elemzését egyváltozós sorba rendezéssel, valamint egyedi részvény szintű elemzést a Fama-MacBeth-regresszióval.

\subsection{A befektetési stratégia elemzése}

Egy adott változó hatásának tesztelése során a szakirodalomban bevett módszer az egyváltozós sorba rendezés. Ez egy kereskedési stratégia hozamának vizsgálata, mely egy adott változó szerint a magas értékkel rendelkező részvényeket megvásárolja, az alacsony értékűeket pedig eladja. A stratégia hozamának teszteléséhez először 
az ESG- vagy ENV-érték szerint sorba rendezem a részvényeket minden hónapra. Ezután kvantilisekbe sorolom őket így képezve portfóliókat, s ahol a minta elemszáma engedi, ott decilis és tercilis alapon is elvégzem a vizsgálatot (Fama - French 1992). Ez alapján kiszámítom a portfólióhozamokat egyenlő, valamint piaci mérettel (érték) súlyozott formában is, hogy korrigáljunk az esetleges torzításokra (Csillag Neszveda 2020). Egyenlő súlyozás esetén a portfólióban szereplő minden részvénybe ugyanakkora arányban történik befektetés. Piaci mérettel történő súlyozás esetén az adott vállalat piaci hányadával arányosan történik a befektetés, erre a robusztusság tesztelése miatt van szükség. Végül a havi portfólióhozamoknak veszem az átlagát, hogy közelítést kapjak a várható értékükre. A befektetési stratégia hozamát pedig úgy számítom, hogy a felső kvantilist tartalmazó portfólió hozamából kivonom az alsó kvantilisét. A vizsgálni kívánt kereskedési stratégiában tehát lényegében eladásra kerül a legalacsonyabb értékkel rendelkező portfólió, míg a legmagasabb értékkel rendelkező megvételre kerül minden hónapban. Az így elért hozam szignifikanciáját a Newey - West (1987) által kialakított korrigált t-statisztika segítségével vizsgálom. Ez a módszer korrigál az alapvető torzításokra, és jóval robusztusabb eredményt biztosít, mint az autokorreláció vagy a heteroszkedaszticitás. A szokásos 10, 5 és 1 százalékos szignifikanciaszinteket tekintem mérvadónak a vizsgálatok során.

Az egyváltozós sorba rendezés viszonylag egyszerű és könnyen értelmezhető, azonban önmagában bizonyos esetekben félrevezető eredményt nyújthat. Előnye, hogy a vizsgált változó és a hozam közötti kapcsolatról nem szükséges semmilyen feltevéssel élnünk. Hátránya, hogy egyszerre csak egy szempontot tudunk vizsgálni, és előfordulhat, hogy azzal egy másik hatást ragadunk meg. Ennek ellenőrzésére szolgálnak a további kontrollvizsgálatok.

\subsection{Egyedi részvény szintű elemzés}

A Fama-MacBeth-regresszió során lehetőség van több kontrollváltozó használatára és az egyedi részvény szintű információk figyelembevételére. A vizsgálat során először keresztmetszeti regresszióval megbecsülöm a magyarázó változókat minden hónapra. Az ebből kapott havi koefficiensek átlagát veszem, majd szintén a NeweyWest-féle korrigált t-statisztika segítségével vizsgálom. Az eredmények pontosságát a keresztmetszeti regresszió havonta történő alkalmazása biztosítja, ami nem igényli az idősorok vizsgálata esetén szükséges feltevéseket.

Mindkét módszertannak megvannak az előnyei és hátrányai. Ha csak egyetlen módszerrel vizsgáljuk a kérdést, az nagymértékben torzíthatja a kapott eredményeket, ezért van szükség a leírt, viszonylag komplex és átfogó vizsgálatra. 


\section{Adatok}

A pénzügyi kutatások jelentős része az Amerikai Egyesül Államok tőzsdéire és részvényeinek hozamára koncentrálódik. Emellett ezen a piacon igen elterjedt már az ESG alapú befektetés. Ezért tanulmányomban a New York-i tőzsdén (NYSE) jegyzett részvényeket vizsgálom. E piac esetében elsősorban CRSP-adatbázist szokás használni (Fama - French 2018), de hozzáférés hiányában a második legnépszerübb és szintén megbízható (Mérő et al. 2019, Ince - Porter 2006) Thomson Reuters Datastream adatbázist használtam. Ebben az esetben különösen fontos a megfelelő adattisztítások elvégzése, követve Ince - Porter (2006) tanulmányát. Az adatbázis előnye, hogy elérhető az úgynevezett „total return index”, mely az osztalékkal és részvényszám változásával korrigált érték, így ezek torzítása könnyen kiküszöbölhető. Ezen túlmenően az adatbázis tartalmazza a korábban kereskedett, de tőzsdéről már kivezetett részvényeket is, melyekre szintén szükség van a túlélési torzítás (Shumway 1997) elkerüléséhez.

Az adattisztításban az Ince - Porter (2006) által javasolt eljárásokat követem néhány kiegészítéssel. Az adathibák kiszűrése érdekében a 200 százaléknál magasabb havi (nem évesített) hozamokat törlöm, törlöm továbbá a kereskedési (turnover) adatok alapján a nem kereskedett részvények adatait is (Amihud 2002). Ince - Porter (2006) tanulmányában javasolja az alacsony áron kereskedett részvények törlését, mivel azok torzításokat okozhatnak. Az amerikai részvénypiacok esetén ez a határ leggyakrabban 5 dollár, vagyis kihagyom az elemzésből az összes olyan megfigyelést, amikor a részvény ára nem éri el a küszöbértéket. $A z$ alacsony piaci kapitalizációval rendelkező cégek elhagyását is szokás alkalmazni, ha csökkenteni akarjuk annak a valószínúségét, hogy az eredményeket nagymértékben a kis cégek részvényei hajtsák (Mérö et al. 2019). Jelen tanulmányban a piaci méret alapján a legkisebb 5 százalékba tartozó megfigyeléseket töröltem. A változókat 1 százalékos szinten winzorizáltam, nem csökkentve így a megfigyelések számát, de a csökkentve az outlier értékek hatását. A minél pontosabb eredmények érdekében megköveteltem, hogy a vizsgált időszakban (minden hónapra külön-külön) legalább 500 részvényre legyen ESG- és ENV-pont. Az említett tisztítások és szűrési feltételek után az adatbázisban 87344 darab adat szerepel a New York-i tőzsdéről a 2007. január 1. és 2019. december 1. közötti időszakra. A robusztusság vizsgálatánál pedig a rövidebb időszak 2013. január 1 és 2019. december 1. közé esik. Erre később részletesebben kitérek.

\section{Eredmények}

\subsection{ESG és ENV a teljes piacon}

Először a teljes piacon vizsgálom a 2. fejezetben leírt befektetési stratégia jövedelmezőségét az ESG és az ENV alapján. Alkalmazok tercilis és decilis alapú sorba rendezést is, azt feltételezve, hogy a részletesebb felbontású decilisre érzékenyebb a piac. Ez azonban nem igazolható, mivel az ESG esetében sem tercilis, sem decilis 
alapú beosztást alkalmazva nem szignifikáns a hozam, ráadásul enyhén negatív is (1. táblázat). A robusztusságot megerősíti, hogy az egyenlő vagy piaci érték súlyozásnak jelen esetben nincs nagy hatása, az érték súlyozás sem mozdítja el az eredményeket.

\begin{tabular}{|c|c|c|c|c|c|c|}
\hline \multicolumn{7}{|c|}{ 1. táblázat } \\
\hline & \multirow{2}{*}{ Kvantilis } & \multirow{2}{*}{ Átlag-ESG } & \multicolumn{2}{|c|}{$\begin{array}{c}\text { Egyenlően súlyozott } \\
\text { portfólió }\end{array}$} & \multicolumn{2}{|c|}{$\begin{array}{c}\text { Értékkel súlyozott } \\
\text { portfólió }\end{array}$} \\
\hline & & & Átlaghozam & $\begin{array}{l}\text { Newey- } \\
\text { West t }\end{array}$ & Átlaghozam & $\begin{array}{l}\text { Newey- } \\
\text { West t }\end{array}$ \\
\hline \multirow{7}{*}{ ESG } & 1. & 22,27 & $0,92 \%$ & $(2,30)^{* *}$ & $0,91 \%$ & $(2,29) * *$ \\
\hline & 2. & 41,70 & $0,88 \%$ & $(2,17)^{* *}$ & $0,88 \%$ & $(2,19)^{* *}$ \\
\hline & 3. & 69,27 & $0,91 \%$ & $(2,63) * * *$ & $0,91 \%$ & $(2,66) * * *$ \\
\hline & $3 .-1$. & - & $-0,01 \%$ & $-(0,09)$ & $0,00 \%$ & $-(0,05)$ \\
\hline & 1. & 15,54 & $0,97 \%$ & $(2,48)^{* *}$ & $0,88 \%$ & $(2,86)^{* * *}$ \\
\hline & 10. & 79,82 & $0,88 \%$ & $(2,87)^{* * *}$ & $0,96 \%$ & $(2,46)^{* *}$ \\
\hline & 10.-1. & - & $-0,09 \%$ & $-(0,75)$ & $-0,08 \%$ & $-(0,69)$ \\
\hline
\end{tabular}

Megjegyzés: Az 1. portfólióba kerültek a legkisebb, míg a 3. (vagy 10.) portfólióba a legnagyobb ESG-értékkel rendelkező részvények. *** 1 százalékon, ** 5 százalékon, * 10 százalékon szignifikáns.

Az ENV esetében hasonlóak az eredmények. Sem tercilis, sem decilis alapú beosztás esetén nem szignifikáns, enyhe negatív hozam látható (2. táblázat). Hasonló feltételezésekkel élhetünk, mint az előző esetben, tehát hogy a piac a kiugró értékekre érzékenyebb, de ez itt sem mutatható ki. Az egyenlő vagy piaci súlyozás sem hat az eredményre, ami a robusztusságot erősíti meg.

\section{2. táblázat}

ENV, tercilis és decilis alapú sorba rendezés (2007-2019, teljes piac)

\begin{tabular}{|c|c|c|c|c|c|c|}
\hline & \multirow{2}{*}{ Kvantilis } & \multirow{2}{*}{ Átlag-ENV } & \multicolumn{2}{|c|}{$\begin{array}{c}\text { Egyenlően súlyozott } \\
\text { portfólió }\end{array}$} & \multicolumn{2}{|c|}{$\begin{array}{c}\text { Értékkel súlyozott } \\
\text { portfólió }\end{array}$} \\
\hline & & & Átlaghozam & $\begin{array}{l}\text { Newey- } \\
\text { West t }\end{array}$ & Átlaghozam & $\begin{array}{c}\text { Newey- } \\
\text { West t }\end{array}$ \\
\hline \multirow{7}{*}{ ENV } & 1. & 9,25 & $0,99 \%$ & $(3,07)^{* * *}$ & $0,99 \%$ & $(3,09)^{* * *}$ \\
\hline & 2. & 37,05 & $1,00 \%$ & $(3,11)^{* * *}$ & $1,00 \%$ & $(3,13)^{* * *}$ \\
\hline & 3. & 72,24 & $0,94 \%$ & $(3,49)^{* * *}$ & $0,93 \%$ & $(3,52)^{* * *}$ \\
\hline & 3.-1. & - & $-0,05 \%$ & $-(0,64)$ & $-0,05 \%$ & $-(0,65)$ \\
\hline & 1. & 3,12 & $0,95 \%$ & $(2,84)^{* * *}$ & $0,87 \%$ & $(3,13)^{* * *}$ \\
\hline & 10. & 84,19 & $0,87 \%$ & $(3,13)^{* * *}$ & $0,96 \%$ & $(2,76)^{* * *}$ \\
\hline & 10.-1. & - & $-0,08 \%$ & $-(0,76)$ & $-0,09 \%$ & $-(0,74)$ \\
\hline
\end{tabular}

Megjegyzés: Az 1. portfólióba kerültek a legkisebb, míg a 3. (vagy 10.) portfólióba a legnagyobb ENV-értékkel rendelkező részvények. *** 1 százalékon, ** 5 százalékon, * 10 százalékon szignifikáns. 
A Fama-Macbeth-regressziók esetében szignifikáns negatív koefficienseket láthatunk, azonban azok értéke jóval kisebb a többi faktorénál (3. táblázat). Ezért az ESG és ENV hatásának gazdasági jelentősége elhanyagolható. Ez lényegében összecseng az egyváltozós sorba rendezés eredményeivel mindkét változó esetében, ahol nem szignifikáns eredményeket kaptam.

\begin{tabular}{|c|c|c|}
\hline \multicolumn{3}{|c|}{$\begin{array}{l}\text { 3. táblázat } \\
\text { ESG és ENV Fama-MacBeth-regresszió (2007-2019, teljes piac) }\end{array}$} \\
\hline Változó & 1 & 2 \\
\hline ESG & $\begin{array}{c}-0,0059 \\
-(4,45)^{* * *}\end{array}$ & - \\
\hline ENV & - & $\begin{array}{l}-0,0037 \\
-(4,11)^{* * *}\end{array}$ \\
\hline Beta & $\begin{array}{r}0,0859 \\
(0,18)\end{array}$ & $\begin{array}{l}0,0375 \\
(0,10)\end{array}$ \\
\hline Size & $\begin{array}{c}0,1098 \\
(4,30)^{* * *}\end{array}$ & $\begin{array}{c}0,0821 \\
(4,32)^{* * *}\end{array}$ \\
\hline Btm & $\begin{array}{c}-0,2412 \\
-(6,61)^{* * *}\end{array}$ & $\begin{array}{r}-0,2218 \\
-(6,93)^{* * *}\end{array}$ \\
\hline Mom & $\begin{array}{l}-0,8507 \\
-(1,59)\end{array}$ & $\begin{array}{l}-0,4613 \\
-(1,03)\end{array}$ \\
\hline \multicolumn{3}{|c|}{$\begin{array}{l}\text { Megjegyzés: A regressziókban a hozamokat ESG-vel vagy ENV-vel, valamint kontrollváltozókkal magya- } \\
\text { ráztam, melyek a piaci béta (Beta), piaci méret (Size), könyv szerinti érték és piaci érték hányadosa (Btm) } \\
\text { és a momentum (Mom). A táblázatban a koefficiensek idősoros átlaga (x100), valamint zárójelben } \\
\text { a hozzá tartozó Newey-West-féle t-statisztika látható. }{ }^{* * *} 1 \text { százalékon, }{ }^{* *} 5 \text { százalékon, * } 10 \text { százalé- } \\
\text { kon szignifikáns. }\end{array}$} \\
\hline
\end{tabular}

Összességében a teljes piacot vizsgálva gyenge negatív kapcsolat látható a vizsgált mutatók és a részvényhozamok között. A kapcsolat iránya egyhangúan negatív irányba mutat, de szignifikanciája mind statisztikai, mind gazdasági szempontból erősen megkérdőjelezhető. Ez alapján a felelős és fenntartható befektetésektől feltételezett nagyobb profit egyelőre elmarad, sőt akár kisebb hozamveszteség fordulhat elő. A feltett hipotézist az eddigiek alapján a teljes piacot vizsgálva elutasítom.

\subsection{Részletes iparági bontás}

A teljes piac vizsgálatánál részletesebb elemzésre van szükség ahhoz, hogy átfogó képet kapjunk a felelős és fenntartható befektetések jövedelmezőségéről. A különböző iparágak számos sajátossággal rendelkeznek, például eltérő környezetvédelmi feltételekkel és adottságokkal. Így kézenfekvő az iparági bontás vizsgálata. Ebben az alfejezetben a teljes piacot 25 fő iparágra bontom. Azt feltételezem, hogy az iparágon belül nagyobb mértékben számít a felelős magatartás, és hogy ez a közvetlen versenytársak (azonos iparági szereplők) esetében fontos lehet (Kumar et al. 2016). 
Számos pszichológiai és viselkedési közgazdaságtani tanulmány ${ }^{4}$ azt találta, hogy az emberek hajlamosak a kontextus ${ }^{5}$ alapján dönteni, és nem önmagában kezelni az adott értékeket. Ezek alapján hipotézisem, hogy ha az eddigi befektetési stratégiát iparágakon belül alkalmazom, akkor nagyobb profitot érhetek el. Az adatok felbontása miatt csökken a mintaelemszám, így ebben az esetben csak a tercilis alapú stratégia hozamát vizsgálom.

Az ESG esetében (4. táblázat) minden szokásos szignifikanciaszinten szignifikáns pozitív kapcsolat egyedül a ruházati iparágban látható, havi 0,62 százalékos hozamot jelent. A szállítmányozó iparban látható valamelyest pozitív hozam még, de ez 10 százalékos szinten sem szignifikáns. A vizsgált 25 iparágból 4 helyen látható szignifikáns negatív hozam, ezek a textil, dohány, vegyes és autóipar. Közös jellemzőjük, hogy egyik sem kifejezetten környezetbarát, továbbá mindegyik szektorban viszonylag alacsony az átlagos ESG-pontszám. A többi szektor nagy részében inkább negatív, de nem szignifikáns hozamok mutathatók ki. A piaci értékkel súlyozott hozamok az eredmények robusztusságát erősítik meg.

\begin{tabular}{|c|c|c|c|c|}
\hline \multicolumn{5}{|l|}{ 4. táblázat } \\
\hline \multirow[b]{2}{*}{ Iparág } & \multicolumn{2}{|c|}{ Egyenlően súlyozott portfólió } & \multicolumn{2}{|c|}{ Értékkel súlyozott portfólió } \\
\hline & Átlaghozam & Newey-West $t$ & Átlaghozam & Newey-West $t$ \\
\hline Ruházati (16) & $0,62 \%$ & $(2,75)^{* * *}$ & $0,64 \%$ & $(2,92)^{* * *}$ \\
\hline Autó (19) & $-0,52 \%$ & $-(1,98)^{* *}$ & $-0,52 \%$ & $-(2,04)^{* *}$ \\
\hline Textil (73) & $-1,70 \%$ & $-(3,25)^{* *}$ & $-1,71 \%$ & $-(3,25)^{* * *}$ \\
\hline Dohány (76) & $-0,16 \%$ & $-(1,65)^{*}$ & $-0,15 \%$ & $-(1,46)$ \\
\hline Szállítmányozó (79) & $0,31 \%$ & $(1,15)$ & $0,30 \%$ & $(1,11)$ \\
\hline Vegyes (85) & $-0,17 \%$ & $-(1,69)^{*}$ & $-0,16 \%$ & $-(1,57)$ \\
\hline \multicolumn{5}{|c|}{$\begin{array}{l}\text { Megjegyzés: A táblázat az ESG alapján, tercilis alapú beosztásra képzett befektetési stratégia hozamá } \\
\text { mutatja, melyet úgy kapok, hogy a felső tercilist tartalmazó portfólió hozamából kivonom az alsó terci } \\
\text { lis hozamát. A táblázatban csak a jelentösebb (a szignifikáns vagy közel szignifikáns) eredmények szere } \\
\text { pelnek. (A teljes táblázat kérés esetén elérhető.) *** } 1 \text { százalékon, ** } 5 \text { százalékon, * } 10 \text { százalékor } \\
\text { szignifikáns. }\end{array}$} \\
\hline
\end{tabular}

Az ENV-t vizsgálva (5. táblázat) szignifikáns pozitív kapcsolat ugyanúgy csak egyedül a ruházati iparban látható. A havi 0,49 százalékos hozam itt csak 10 százalékos szignifikanciaszinten szignifikáns. A szállítmányozó iparban is hasonló eredmények láthatók, mint az ESG esetében. Több iparág esetében is szignifikáns negatív hozamot láthatunk, ezek a textil-, dohány-, autó-, elektromos, olaj-, gáz- és szén-, diverzifikált és élelmiszer-iparágak, de az iparágak többségében itt sem szignifikáns a kapott eredmény.

\footnotetext{
${ }^{4}$ Több mű is született a viselkedési tanulmányok összefoglalására (például Golovics 2015; Neszveda 2018)

${ }^{5}$ A kontextusfüggőségről és jelentőségéről számos közgazdasági modell született (például Kőszegi - Szeidl 2013; Bordalo et al. 2013; Bakó et al., 2018; Bakó - Neszveda 2020).
} 


\begin{tabular}{|c|c|c|c|c|}
\hline \multicolumn{5}{|l|}{$\begin{array}{l}\text { 5. táblázat } \\
\text { ENV, tercilis }\end{array}$} \\
\hline \multirow[b]{2}{*}{ Iparág } & \multicolumn{2}{|c|}{ Egyenlően súlyozott portfólió } & \multicolumn{2}{|c|}{ Értékkel súlyozott portfólió } \\
\hline & Átlaghozam & Newey-West $t$ & Átlaghozam & Newey-West $t$ \\
\hline Ruházati (16) & $0,49 \%$ & $(1,81)^{*}$ & $0,50 \%$ & $(1,83)^{*}$ \\
\hline Autó (19) & $-0,47 \%$ & $-(2,45)^{* *}$ & $-0,50 \%$ & $-(2,67)^{* * *}$ \\
\hline Diverzifikált (31) & $-0,28 \%$ & $-(2,14)^{* *}$ & $-0,31 \%$ & $-(2,35)^{* *}$ \\
\hline Elektromos & $-1,44 \%$ & $-(4,90)^{* * *}$ & $-1,40 \%$ & $-(4,20)^{* * *}$ \\
\hline Élelmiszer (46) & $-0,32 \%$ & $-(1,68)^{*}$ & $-0,33 \%$ & $-(1,70)^{*}$ \\
\hline Olaj, gáz és szén (58) & $-0,41 \%$ & $-(2,21)^{* *}$ & $-0,42 \%$ & $-(2,24)^{* *}$ \\
\hline Textil (73) & $-0,45 \%$ & $-(2,56)^{* *}$ & $-0,39 \%$ & $-(2,11)^{* *}$ \\
\hline Dohány (76) & $-0,33 \%$ & $-(1,88)$ & $-0,26 \%$ & $-(1,45)$ \\
\hline Szállítmányozó (79) & $0,31 \%$ & $(1,33)$ & $0,30 \%$ & $(1,29)$ \\
\hline
\end{tabular}

Összességében elég vegyes képet kapunk, amely megegyezik Cao et al. (2020) eredményeivel. Néhány iparág elkülöníthető, ahol jelentősége lehet a felelős és fenntartható magatartásnak, de ezekben is inkább a negatív kapcsolat figyelhető meg. A negatív hozam főleg az alacsonyabb ESG- vagy ENV-minősítéssel rendelkező iparágakban látható. Ez azt mutatja, hogy a befektetők egyelöre nem feltétlenül értékelik a fenntarthatóságot (Kumar et al. 2016), sőt a szennyezőbb szektorokban ez még hátrányt is jelenthet. A vizsgálat alapján elutasítom a hipotézisem, miszerint az eddigi befektetési stratégiák iparágakon belüli alkalmazásával nagyobb profit érhető el.

\subsection{Csoportos vizsgálat}

Az eddigi eredmények azt mutatják, hogy az iparágakban az átlagos ESG- vagy ENV-pontszám befolyásolhatja a hozamok alakulását. Ennek további vizsgálata érdekében az eddig vizsgált 25 iparágat 5 csoportra osztom (minden csoportba 5 iparág kerül) az alapján, hogy nagyon alacsony, alacsony, közepes, magas vagy nagyon magas az iparági átlagpontszám. Ebben a fejezetben az így alkotott csoportokon végzett tesztek eredményeit ismertetem. Hipotézisem, hogy ha az eddigi befektetési stratégiát csoportokon belül alkalmazom, akkor nagyobb profitot érhetek el.

A várakozással ellentétben az eredmények (6. táblázat) azt mutatják, hogy az ESGnek nincs hatása a hozamok alakulására. Egyik portfólió hozama sem szignifikáns. A decilis alapú beosztás esetén valamivel kedvezőbbek az eredmények, a nagyon magas ESG-értékű csoportban képzett portfólió hozama közel áll a szignifikánshoz, de így sem fogadhatjuk el még 10 százalékos szinten sem. Az értéksúlyozás is megerősíti az eredményeket, az eltérések elhanyagolhatók. 


\section{6. táblázat}

ESG, tercilis és decilis alapú sorba rendezés (2007-2019, iparági csoportosítás)

\begin{tabular}{|c|c|c|c|c|c|c|}
\hline & \multirow{2}{*}{ Kvantilis } & \multirow{2}{*}{ Átlag-ESG } & \multicolumn{2}{|c|}{$\begin{array}{c}\text { Egyenlően súlyozott } \\
\text { portfólió }\end{array}$} & \multicolumn{2}{|c|}{$\begin{array}{c}\text { Értékkel súlyozott } \\
\text { portfólió }\end{array}$} \\
\hline & & & Átlaghozam & $\begin{array}{l}\text { Newey- } \\
\text { West t }\end{array}$ & Átlaghozam & $\begin{array}{l}\text { Newey- } \\
\text { West t }\end{array}$ \\
\hline \multirow{4}{*}{$\begin{array}{l}\text { Nagyon alacsony } \\
(28,55,58,73,49)\end{array}$} & 1. & 17,93 & $0,83 \%$ & $(1,97)^{* *}$ & $0,83 \%$ & $(1,96) * *$ \\
\hline & 2. & 31,66 & $0,80 \%$ & $(2,08)^{* *}$ & $0,80 \%$ & $(2,09)^{* *}$ \\
\hline & 3. & 59,21 & $0,76 \%$ & $(1,80)^{*}$ & $0,76 \%$ & $(1,84)^{*}$ \\
\hline & 3.-1. & - & $-0,07 \%$ & $-(0,82)$ & $-0,07 \%$ & $-(0,73)$ \\
\hline \multirow{4}{*}{$\begin{array}{l}\text { Alacsony } \\
(85,43,37,13,79)\end{array}$} & 1. & 21,60 & $0,91 \%$ & $(2,27)^{* *}$ & $0,91 \%$ & $(2,26)^{* *}$ \\
\hline & 2. & 38,46 & $0,89 \%$ & $(2,13)^{* *}$ & $0,89 \%$ & $(2,14)^{* *}$ \\
\hline & 3. & 64,26 & $0,85 \%$ & $(2,02)^{* *}$ & $0,85 \%$ & $(2,04)^{* *}$ \\
\hline & $3 .-1$. & - & $-0,06 \%$ & $-(0,76)$ & $-0,06 \%$ & $-(0,72)$ \\
\hline \multirow{4}{*}{$\begin{array}{l}\text { Közepes } \\
(19,67,52,40,61)\end{array}$} & 1. & 23,56 & $1,03 \%$ & $(2,33)^{* *}$ & $1,03 \%$ & $(2,34)^{* *}$ \\
\hline & 2. & 44,51 & $0,82 \%$ & $(1,72)^{*}$ & $0,82 \%$ & $(1,73)^{*}$ \\
\hline & 3. & 70,43 & $0,92 \%$ & $(2,53)^{* *}$ & $0,93 \%$ & $(2,58)^{* * *}$ \\
\hline & 3.-1. & - & $-0,10 \%$ & $-(0,81)$ & $-0,10 \%$ & $-(0,78)$ \\
\hline \multirow{4}{*}{$\begin{array}{l}\text { Magas } \\
(64,25,82,70,16)\end{array}$} & 1. & 26,21 & $0,93 \%$ & $(2,35)^{* *}$ & $0,92 \%$ & $(2,35)^{* *}$ \\
\hline & 2. & 48,26 & $0,92 \%$ & $(2,42) * *$ & $0,92 \%$ & $(2,43)^{* *}$ \\
\hline & 3. & 71,75 & $0,90 \%$ & $(2,94)^{* * *}$ & $0,90 \%$ & $(2,97)^{* * *}$ \\
\hline & $3 .-1$. & - & $-0,03 \%$ & $-(0,22)$ & $-0,02 \%$ & $-(0,18)$ \\
\hline \multirow{4}{*}{$\begin{array}{l}\text { Nagyon magas } \\
(34,22,31,46,76)\end{array}$} & 1. & 29,54 & $1,06 \%$ & $(3,06)^{* * *}$ & $1,06 \%$ & $(3,05)^{* * *}$ \\
\hline & 2. & 56,18 & $1,05 \%$ & $(3,08)^{* * *}$ & $1,05 \%$ & $(3,09)^{* * *}$ \\
\hline & 3. & 79,14 & $0,96 \%$ & $(3,72)^{* * *}$ & $0,96 \%$ & $(3,69) * * *$ \\
\hline & 3.-1. & - & $-0,10 \%$ & $-(0,63)$ & $-0,09 \%$ & $-(0,60)$ \\
\hline Nagyon alacsony & 10.-1. & - & $-0,07 \%$ & $-(0,54)$ & $-0,08 \%$ & $-(0,64)$ \\
\hline Alacsony & 10.-1. & - & $-0,13 \%$ & $-(1,05)$ & $-0,11 \%$ & $-(0,93)$ \\
\hline Közepes & $10 .-1$. & - & $-0,06 \%$ & $-(0,32)$ & $-0,03 \%$ & $-(0,14)$ \\
\hline Magas & 10.-1. & - & $-0,08 \%$ & $-(0,45)$ & $-0,09 \%$ & $-(0,46)$ \\
\hline Nagyon magas & 10.-1. & - & $-0,28 \%$ & $-(1,46)$ & $-0,26 \%$ & $-(1,34)$ \\
\hline
\end{tabular}

Megjegyzés: Az 1. portfólióba kerültek a legkisebb, míg a 3. (vagy 10.) portfólióba a legnagyobb ESG-értékkel rendelkező részvények a csoporton belül. *** 1 százalékon, ** 5 százalékon, * 10 százalékon szignifikáns.

Az ENV esetében hasonlók az eredmények (7. táblázat), azzal az eltéréssel, hogy itt a tercilis alapú beosztás esetében a nagyon alacsony csoportban kapunk majdnem szignifikáns eredményt. A kapott eredmények egyáltalán nem tekinthetők szignifikánsak. Az előzetes feltételezés, miszerint az iparág átlagos ESG- vagy ENV-pontszáma meghatározó lehet, nem nyer igazolást. 


\section{7. táblázat}

\section{ENV, tercilis és decilis alapú sorba rendezés (2007-2019, iparági csoportosítás)}

\begin{tabular}{|c|c|c|c|c|c|c|}
\hline & \multirow{2}{*}{ Kvantilis } & \multirow{2}{*}{ Átlag-ENV } & \multicolumn{2}{|c|}{$\begin{array}{c}\text { Egyenlően súlyozott } \\
\text { portfólió }\end{array}$} & \multicolumn{2}{|c|}{$\begin{array}{c}\text { Értékkel súlyozott } \\
\text { portfólió }\end{array}$} \\
\hline & & & Átlaghozam & $\begin{array}{l}\text { Newey- } \\
\text { West t }\end{array}$ & Átlaghozam & $\begin{array}{l}\text { Newey- } \\
\text { West t }\end{array}$ \\
\hline \multirow{4}{*}{$\begin{array}{l}\text { Nagyon alacsony }(28, \\
55,85,73,43)\end{array}$} & 1. & 6,81 & $0,99 \%$ & $(3,00)^{* * *}$ & $0,98 \%$ & $(2,98)^{* * *}$ \\
\hline & 2. & 27,58 & $1,03 \%$ & $(3,02)^{* * *}$ & $1,03 \%$ & $(3,03) * * *$ \\
\hline & 3. & 64,84 & $0,85 \%$ & $(2,40)^{* *}$ & $0,86 \%$ & $(2,42)^{* *}$ \\
\hline & $3 .-1$. & - & $-0,13 \%$ & $-(1,47)$ & $-0,13 \%$ & $-(1,37)$ \\
\hline \multirow{4}{*}{$\begin{array}{l}\text { Alacsony }(49,58,70, \\
13,19)\end{array}$} & 1. & 7,10 & $0,94 \%$ & $(2,14)^{* *}$ & $0,94 \%$ & $(2,16)^{* *}$ \\
\hline & 2. & 32,48 & $0,85 \%$ & $(2,41)^{* *}$ & $0,85 \%$ & $(2,42)^{* *}$ \\
\hline & 3. & 74,34 & $0,95 \%$ & $(3,09)^{* * *}$ & $0,94 \%$ & $(3,13) * * *$ \\
\hline & 3.-1. & - & $-0,13 \%$ & $-(1,15)$ & $-0,13 \%$ & $-(1,16)$ \\
\hline \multirow{4}{*}{$\begin{array}{l}\text { Közepes }(40,64,52,67 \text {, } \\
\text { 79) }\end{array}$} & 1. & 10,96 & $0,99 \%$ & $(2,67)^{* * *}$ & $0,99 \%$ & $(2,68)^{* * *}$ \\
\hline & 2. & 39,63 & $0,95 \%$ & $(2,71)^{* * *}$ & $0,95 \%$ & $(2,74)^{* * *}$ \\
\hline & 3. & 71,95 & $1,01 \%$ & $(3,31)^{* * *}$ & $1,01 \%$ & $(3,37)^{* * *}$ \\
\hline & 3.-1. & - & $0,02 \%$ & $(0,14)$ & $0,02 \%$ & $(0,15)$ \\
\hline \multirow{4}{*}{$\begin{array}{l}\text { Magas }(37,16,34,82 \text {, } \\
25)\end{array}$} & 1. & 14,99 & $1,07 \%$ & $(3,60)^{* * *}$ & $1,07 \%$ & $(3,60)^{* * *}$ \\
\hline & 2. & 45,36 & $1,06 \%$ & $(4,05)^{* * *}$ & $1,06 \%$ & $(4,07)^{* * *}$ \\
\hline & 3. & 73,79 & $0,99 \%$ & $(4,36)^{* * *}$ & $0,98 \%$ & $(4,37)^{* * *}$ \\
\hline & 3.-1. & - & $-0,10 \%$ & $-(0,82)$ & $-0,10 \%$ & $-(0,85)$ \\
\hline \multirow{4}{*}{$\begin{array}{l}\text { Nagyon magas }(31,22 \text {, } \\
61,46,76)\end{array}$} & 1. & 19,23 & $0,97 \%$ & $(2,54)^{* *}$ & $0,97 \%$ & $(2,56)^{* *}$ \\
\hline & 2. & 50,80 & $1,02 \%$ & $(3,51)^{* * *}$ & $1,02 \%$ & $(3,55)^{* * *}$ \\
\hline & 3. & 77,46 & $0,99 \%$ & $(3,84)^{* * *}$ & $0,98 \%$ & $(3,78)^{* * *}$ \\
\hline & 3.-1. & - & $0,05 \%$ & $(0,35)$ & $0,04 \%$ & $(0,27)$ \\
\hline Nagyon alacsony & 10.-1. & - & $0,03 \%$ & $(0,17)$ & $0,01 \%$ & $(0,04)$ \\
\hline Alacsony & 10.-1. & - & $-0,18 \%$ & $-(1,07)$ & $-0,25 \%$ & $-(1,29)$ \\
\hline Közepes & $10 .-1$. & - & $-0,12 \%$ & $-(0,70)$ & $-0,13 \%$ & $-(0,64)$ \\
\hline Magas & $10 .-1$. & - & $-0,05 \%$ & $-(0,32)$ & $0,00 \%$ & $-(0,04)$ \\
\hline Nagyon magas & $10 .-1$ & - & $0,06 \%$ & $(0,27)$ & $0,13 \%$ & $(0,58)$ \\
\hline
\end{tabular}

Megjegyzés: Az 1. portfólióba kerültek a legkisebb, míg a 3. (vagy 10.) portfólióba a legnagyobb ENV-értékkel rendelkező részvények a csoporton belül. *** 1 százalékon, ** 5 százalékon, * 10 százalékon szignifikáns.

A teljes piac vizsgálata esetében a Fama-Macbeth-regresszió alkalmazásakor kaptam statisztikailag szignifikáns eredményeket, így ez érdekes lehet csoportos felbontás esetén is. Az ESG-t használva magyarázó változóként (8. táblázat), a közepes csoportot leszámítva mindegyiknél szignifikánsan negatív a kapcsolat. A teljes piachoz hasonlóan az ESG koefficiense kisebb, mint a kontroll faktoroké, gazdasági 
jelentősége elhanyagolható. Annyi látható, hogy a szélső csoportoknál a koefficiens nagyobb.

ENV-t használva magyarázó változóként (9. táblázat), szintén a közepes csoportot leszámítva, minden esetben szignifikáns negatív koefficiens látható. Megfigyelhető az is, hogy a szélső csoportoknál erősebb a hatás. A legerősebb a nagyon magas ENV-értékű csoportban, de gazdasági szignifikanciája még ott is elhanyagolható.

\section{8. táblázat}

ESG, Fama-MacBeth-regresszió (2007-2019, iparági csoportosítás)

\begin{tabular}{|c|c|c|c|c|c|}
\hline Változó & 1 & 2 & 3 & 4 & 5 \\
\hline Nagyon alacsony & $\begin{array}{l}-0,0060 \\
-(2,53)^{* *}\end{array}$ & - & - & - & - \\
\hline Alacsony & - & $\begin{array}{c}-0,0058 \\
-(3,20)^{* * *}\end{array}$ & - & - & - \\
\hline Közepes & - & - & $\begin{array}{c}-0,0030 \\
-(0,12)\end{array}$ & - & - \\
\hline Magas & - & - & - & $\begin{array}{c}-0,0064 \\
-(3,22)^{* * *}\end{array}$ & - \\
\hline Nagyon magas & - & - & - & - & $\begin{array}{c}-0,0088 \\
-(3,07)^{* * *} \\
\end{array}$ \\
\hline Beta & $\begin{array}{c}0,34 \\
(0,66) \\
\end{array}$ & $\begin{array}{c}0,17 \\
(0,32) \\
\end{array}$ & $\begin{array}{r}0,34 \\
(0,64) \\
\end{array}$ & $\begin{array}{l}-0,21 \\
-(0,43)\end{array}$ & $\begin{array}{r}0,19 \\
(0,44) \\
\end{array}$ \\
\hline Size & $\begin{array}{c}0,11 \\
(2,20)^{* *}\end{array}$ & $\begin{array}{c}0,11 \\
(4,08)^{* * *}\end{array}$ & $\begin{array}{c}0,05 \\
(1,41) \\
\end{array}$ & $\begin{array}{c}0,11 \\
(2,15)^{* *}\end{array}$ & $\begin{array}{c}0,06 \\
(1,80)^{*}\end{array}$ \\
\hline Btm & $\begin{array}{c}-0,28 \\
-(5,29)^{* * *}\end{array}$ & $\begin{array}{c}-0,20 \\
-(3,72)^{* * *}\end{array}$ & $\begin{array}{c}-0,39 \\
-(5,51)^{* * *}\end{array}$ & $\begin{array}{c}-0,27 \\
-(7,47)^{* * *}\end{array}$ & $\begin{array}{c}-0,23 \\
-(3,69)^{* * *}\end{array}$ \\
\hline Mom & $\begin{array}{l}0,05 \\
(0,10)\end{array}$ & $\begin{array}{c}-0,79 \\
-(1,41)\end{array}$ & $\begin{array}{c}-0,63 \\
-(1,13)\end{array}$ & $\begin{array}{c}-1,71 \\
-(2,63)^{* * *}\end{array}$ & $\begin{array}{c}-1,38 \\
-(2,30)^{* *}\end{array}$ \\
\hline
\end{tabular}

Megjegyzés: A regressziókban a hozamokat ESG-vel, valamint kontrollváltozókkal magyaráztam, melyek a piaci béta (Beta), piaci méret (Size), könyv szerinti érték és piaci érték hányadosa (Btm) és a momentum (Mom). A táblázatban a koefficiensek idősoros átlaga (x100), valamint zárójelben a hozzátartozó Newey-West-féle t-statisztika látható. *** 1 százalékon, ** 5 százalékon, * 10 százalékon szignifikáns. 


\begin{tabular}{|c|c|c|c|c|c|}
\hline $\begin{array}{l}\text { 9. táblázat } \\
\text { ENV, Fama-Ma }\end{array}$ & eth-regres & (2007-20 & iparági cso & osítás) & \\
\hline Változó & 1 & 2 & 3 & 4 & 5 \\
\hline Nagyon alacsony & $\begin{array}{l}-0,0027 \\
-(1,65)^{*}\end{array}$ & - & - & - & - \\
\hline Alacsony & - & $\begin{array}{l}-0,0039 \\
-(1,66)^{*}\end{array}$ & - & - & - \\
\hline Közepes & - & - & $\begin{array}{l}-0,0018 \\
-(0,95)\end{array}$ & - & - \\
\hline Magas & - & - & - & $\begin{array}{l}-0,0020 \\
-(1,81)^{*}\end{array}$ & - \\
\hline Nagyon magas & - & - & - & - & $\begin{array}{l}-0,0045 \\
-(2,35)^{* *}\end{array}$ \\
\hline Beta & $\begin{array}{l}-0,05 \\
-(0,12)\end{array}$ & $\begin{array}{l}-0,08 \\
-(0,18) \\
\end{array}$ & $\begin{array}{c}0,16 \\
(0,45)\end{array}$ & $\begin{array}{c}0,00 \\
(0,01)\end{array}$ & $\begin{array}{c}0,23 \\
(0,61)\end{array}$ \\
\hline Size & $\begin{array}{c}0,09 \\
(2,58)^{* * *}\end{array}$ & $\begin{array}{c}0,08 \\
(2,14)^{* *}\end{array}$ & $\begin{array}{c}0,11 \\
(2,30)^{* *}\end{array}$ & $\begin{array}{c}0,01 \\
(0,16)\end{array}$ & $\begin{array}{c}0,04 \\
(0,90)\end{array}$ \\
\hline Btm & $\begin{array}{c}-0,23 \\
-(3,61)^{* * *}\end{array}$ & $\begin{array}{c}-0,30 \\
-(4,54)^{* * *}\end{array}$ & $\begin{array}{c}-0,33 \\
-(4,07)^{* * *}\end{array}$ & $\begin{array}{l}-0,19 \\
-(4,47) \\
\end{array}$ & $\begin{array}{c}-0,13 \\
-(1,96)^{* *}\end{array}$ \\
\hline Mom & $\begin{array}{l}-0,30 \\
-(0,47)\end{array}$ & $\begin{array}{l}0,21 \\
(0,32)\end{array}$ & $\begin{array}{l}-0,82 \\
-(1,34)\end{array}$ & $\begin{array}{l}-0,60 \\
-(1,18)\end{array}$ & $\begin{array}{l}-0,78 \\
-(1,14)\end{array}$ \\
\hline
\end{tabular}

Megjegyzés: A regressziókban a hozamokat ENV-vel, valamint kontrollváltozókkal magyaráztam, melyek a piaci béta (Beta), piaci méret (Size), könyv szerinti érték és piaci érték hányadosa (Btm) és a momentum (Mom). A táblázatban a koefficiensek idősoros átlaga (x100) valamint zárójelben a hozzátartozó Newey-West-féle t-statisztika látható. *** 1 százalékon, ** 5 százalékon, * 10 százalékon szignifikáns.

Összeségében az iparági átlagos ESG- és ENV-pontszám alapján való csoportosítások esetében az egyváltozós sorba rendezés alapján történő portfólióképzés nem mutatott szignifikáns hozamot, a Fama-Macbeth-regressziók pedig negatív kapcsolatot mutatnak, de gazdasági jelentősége elenyésző. Ugyanilyen vizsgálatot legjobb tudomásom szerint korábbi tanulmányban nem végeztek, de Auer - Schuhmacher (2016) hasonló vizsgálataival egybevágó eredményeket kaptam, miszerint a magas vagy alacsony besorolás nem eredményez szignifikáns hozamkülönbséget. Továbbá néhány esetben negatív kapcsolat mutatható ki. A fejezet elején feltett hipotézist így elutasítom.

\subsection{Relatív ESG és relatív ENV, csoportos vizsgálat}

Az eddigi vizsgálatok részben arra utalnak, hogy ha a piac általánosan nem értékeli az ESG-t vagy az ENV-t, a szélsőséges értékekre mégis érzékeny lehet. Ebben a fejezetben ennek vizsgálatával foglalkozom. Ennek mérésére a relatív ESG-t és relativ ENV-t használom, melyet úgy számítok, hogy az adott pontszámból kivonom az 
iparági átlagot. Ez megmutatja az iparági átlagtól vett előjeles távolságot. Hipotézisem, hogy a nagyobb relatív pontszámmal rendelkező részvények nagyobb hozamot biztosítanak. Az eddigi eredmények abba az irányba mutatnak, hogy a felelős és fenntartható befektetéseknek alapvetően nincs hatása a hozamokra. Ezért a relatív vizsgálatok egyből a csoportos bontásban kerülnek bemutatásra ${ }^{6}$, a lehető legtöbb pluszinformációt felhasználva a pontszámokból. A teljes iparági bontás ebben az esetben már nem értelmezhető külön, pontosan ugyanazt az eredményt adná, mint a sima pontszámok vizsgálata.

Az relatív ESG alapú stratégia (lásd 10. táblázat) tercilis beosztása esetében nem látható sehol szignifikáns hozam. Decilis alapú beosztás esetében valamivel magasabb hozamokat kaptam, a nagyon magas csoportban 10 százalékos szignifikancia szinten szignifikáns $-0,34$ százalékos havi hozam látható. Mind egyenlő, mind értéksúlyozás esetében egyezőek az eredmények, és azt mutatják, hogy az alapból nagyon magas ESG-pontszámmal rendelkező iparágakban negatív kapcsolat látható az ESG és a hozam között, vagyis nem érdemes a magas ESG-vel rendelkező részvényekbe fektetni.

Az ENV esetében valamelyest eltérő eredményeket kaptam (11. táblázat), a tercilis alapú beosztás esetében a nagyon alacsony kategóriában látható szignifikáns, $-0,18$ százalékos havi hozam (ez is csak 10 százalékos szinten). A decilis alapú beosztás ezt felerősíti -0,34 százalékra, azonban ez érzékenyebb a piaci érték súlyozásra. Ebből az eredményből az látható, hogy az alapból nagyon alacsony ENV-pontszámmal rendelkező iparágakban negatív a kapcsolat az ENV és a hozam között. Tehát nem érdemes itt sem a magas ENV-vel rendelkező részvényekbe fektetni. Fontos azonban megjegyezni, hogy egyik vizsgált mutató esetében sem tekinthetők az eredmények robusztusnak. Csak magas szignifikanciaszint esetében látható néhány helyen szignifikáns hozam, valamint viszonylag sok tesztet hajtok végre, így ez akár a puszta véletlen hatása is lehet.

\footnotetext{
${ }^{6} \mathrm{~A}$ vizsgálatot a teljes piacra is elvégeztem, ott nem volt különösebb hatása az eredményekre, ezért a táblázatok átláthatóságának érdekében nem kerültek be a tanulmányba, kérés esetén elérhetőek.
} 


\section{0. táblázat}

Relatív ESG, tercilis és decilis tercilis alapú sorba rendezés (2007-2019, iparági csoportosítás)

\begin{tabular}{|c|c|c|c|c|c|}
\hline & \multirow[b]{2}{*}{ Kvantilis } & \multicolumn{2}{|c|}{ Egyenlően súlyozott portfólió } & \multicolumn{2}{|c|}{ Értékkel súlyozott portfólió } \\
\hline & & Átlaghozam & $\begin{array}{l}\text { Newey- } \\
\text { West t }\end{array}$ & Átlaghozam & $\begin{array}{l}\text { Newey- } \\
\text { West t }\end{array}$ \\
\hline \multirow{4}{*}{$\begin{array}{l}\text { Nagyon alacsony }(28, \\
55,58,73,49)\end{array}$} & 1. & $0,91 \%$ & $(2,18)^{* *}$ & $0,91 \%$ & $(2,17)^{* *}$ \\
\hline & 2. & $0,90 \%$ & $(2,32)^{* *}$ & $0,90 \%$ & $(2,34)^{* *}$ \\
\hline & 3. & $0,81 \%$ & $(1,93)^{*}$ & $0,81 \%$ & $(1,97)^{* *}$ \\
\hline & 3.-1. & $-0,10 \%$ & $-(1,08)$ & $-0,10 \%$ & $-(0,99)$ \\
\hline \multirow{4}{*}{$\begin{array}{l}\text { Alacsony }(85,43,37 \text {, } \\
13,79)\end{array}$} & 1. & $1,00 \%$ & $(2,50)^{* *}$ & $1,00 \%$ & $(2,49)^{* *}$ \\
\hline & 2. & $0,98 \%$ & $(2,34)^{* *}$ & $0,98 \%$ & $(2,35)^{* *}$ \\
\hline & 3. & $0,93 \%$ & $(2,20)^{* *}$ & $0,93 \%$ & $(2,21)^{* *}$ \\
\hline & 3.-1. & $-0,07 \%$ & $-(0,88)$ & $-0,07 \%$ & $-(0,84)$ \\
\hline \multirow{4}{*}{$\begin{array}{l}\text { Közepes }(19,67,52,40 \text {, } \\
61)\end{array}$} & 1. & $1,13 \%$ & $(2,54)^{* *}$ & $1,13 \%$ & $(2,55)^{* *}$ \\
\hline & 2. & $0,91 \%$ & $(1,91)^{*}$ & $0,91 \%$ & $(1,93)^{*}$ \\
\hline & 3. & $1,01 \%$ & $(2,75)^{* * *}$ & $1,01 \%$ & $(2,81)^{* * *}$ \\
\hline & 3.-1. & $-0,12 \%$ & $-(0,90)$ & $-0,11 \%$ & $-(0,87)$ \\
\hline \multirow{4}{*}{$\begin{array}{l}\text { Magas }(64,25,82,70 \text {, } \\
\text { 16) }\end{array}$} & 1. & $1,02 \%$ & $(2,61)^{* * *}$ & $1,02 \%$ & $(2,62)^{* * *}$ \\
\hline & 2. & $1,01 \%$ & $(2,65)^{* * *}$ & $1,01 \%$ & $(2,66)^{* * *}$ \\
\hline & 3. & $0,99 \%$ & $(3,27)^{* * *}$ & $1,00 \%$ & $(3,31)^{* * *}$ \\
\hline & 3.-1. & $-0,03 \%$ & $-(0,20)$ & $-0,02 \%$ & $-(0,17)$ \\
\hline \multirow{4}{*}{$\begin{array}{l}\text { Nagyon magas }(34,22 \text {, } \\
31,46,76)\end{array}$} & 1. & $1,17 \%$ & $(3,38)^{* * *}$ & $1,16 \%$ & $(3,36)^{* * *}$ \\
\hline & 2. & $1,13 \%$ & $(3,33)^{* * *}$ & $1,13 \%$ & $(3,34)^{* * *}$ \\
\hline & 3. & $1,08 \%$ & $(4,25)^{* * *}$ & $1,08 \%$ & $(4,20)^{* * *}$ \\
\hline & 3.-1. & $-0,09 \%$ & $-(0,55)$ & $-0,08 \%$ & $-(0,53)$ \\
\hline Nagyon alacsony & 10.-1. & $-0,05 \%$ & $-(0,28)$ & $-0,12 \%$ & $-(0,77)$ \\
\hline Alacsony & 10.-1. & $-0,15 \%$ & $-(1,13)$ & $-0,17 \%$ & $-(1,22)$ \\
\hline Közepes & 10.-1. & $-0,12 \%$ & $-(0,56)$ & $-0,14 \%$ & $-(0,63)$ \\
\hline Magas & 10.-1. & $-0,10 \%$ & $-(0,55)$ & $-0,09 \%$ & $-(0,50)$ \\
\hline Nagyon magas & 10.-1. & $-0,34 \%$ & $-(1,80)^{*}$ & $-0,36 \%$ & $-(1,78)^{*}$ \\
\hline
\end{tabular}

Megjegyzés: Az 1. portfólióba kerültek a legkisebb, míg a 3. (vagy 10.) portfólióba a legnagyobb relatív ESG-értékkel rendelkező részvények a csoporton belül. *** 1 százalékon, ** 5 százalékon, * 10 százalékon szignifikáns. 


\section{1. táblázat}

Relatív ENV, tercilis és decilis alapú sorba rendezés (2007-2019, iparági csoportosítás)

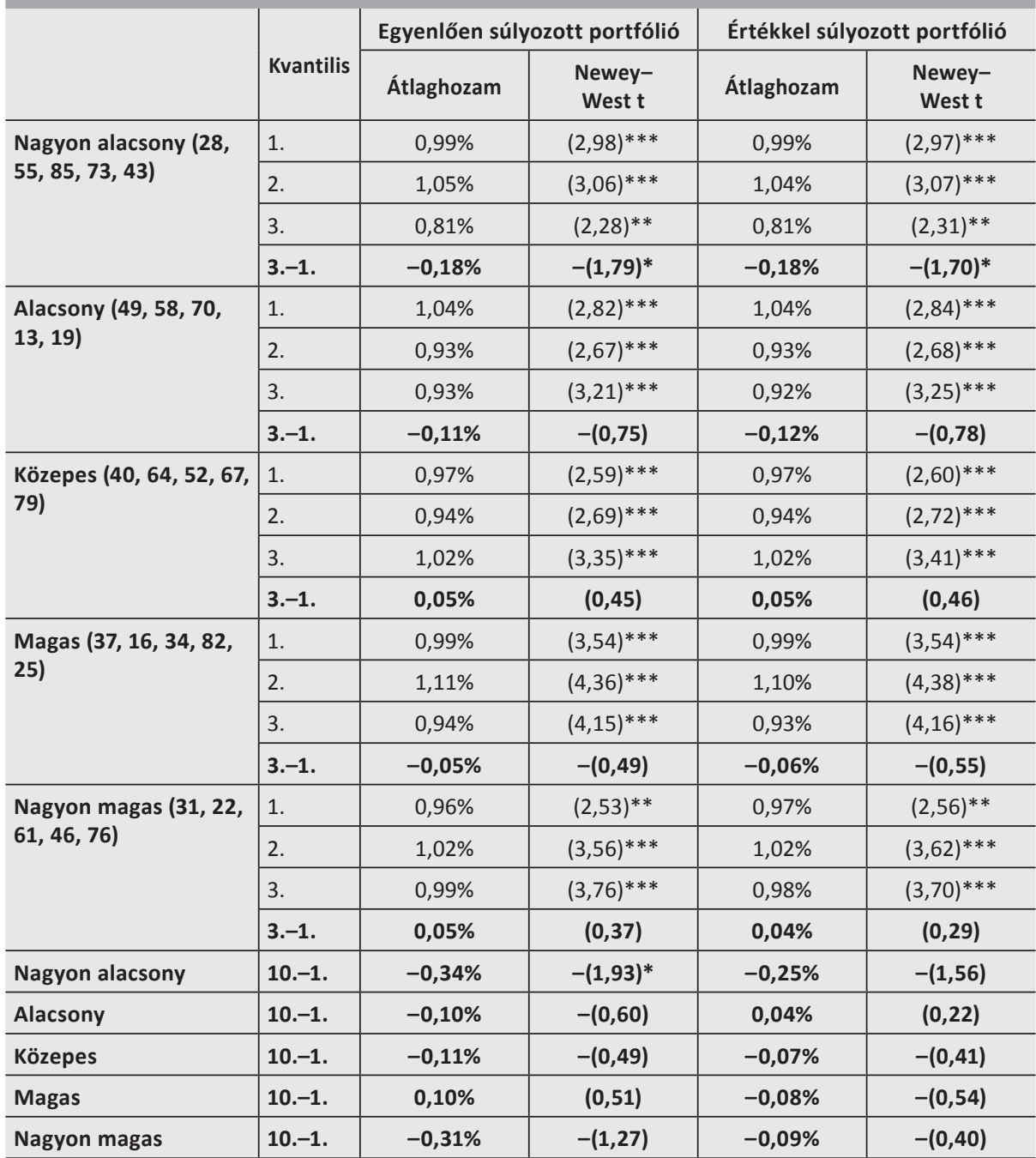

Megjegyzés: Az 1. portfólióba kerültek a legkisebb, míg a 3. (vagy 10.) portfólióba a legnagyobb relatív ENV-értékkel rendelkező részvények a csoporton belül. *** 1 százalékon, ** 5 százalékon, * 10 százalékon szignifikáns. 
Fama-MacBeth-regressziók eredményén (lásd 12. és 13. táblázat) lényegében nem változtat a relatív pontszámok alkalmazása. A közepes csoportot leszámítva, minden esetben szignifikáns negatív kapcsolat látható, viszont ezek gazdasági jelentősége továbbra is elhanyagolható.

\section{2. táblázat \\ Relatív ESG Fama-MacBeth-regresszió (2007-2019, iparági csoportosítás)}

\begin{tabular}{|c|c|c|c|c|c|}
\hline Változó & 1 & 2 & 3 & 4 & 5 \\
\hline Nagyon alacsony & $\begin{array}{c}-0,0066 \\
-(2,78)^{* * *}\end{array}$ & - & - & - & - \\
\hline Alacsony & - & $\begin{array}{c}-0,0063 \\
-(3,52)^{* * *}\end{array}$ & - & - & - \\
\hline Közepes & - & - & $\begin{array}{l}-0,0033 \\
-(0,13) \\
\end{array}$ & - & - \\
\hline Magas & - & - & - & $\begin{array}{c}-0,0070 \\
-(3,54)^{* * *}\end{array}$ & - \\
\hline Nagyon magas & - & - & - & - & $\begin{array}{c}-0,0096 \\
-(3,38)^{* * *}\end{array}$ \\
\hline Beta & $\begin{array}{c}0,37 \\
(0,73) \\
\end{array}$ & $\begin{array}{l}0,18 \\
(0,35) \\
\end{array}$ & $\begin{array}{c}0,37 \\
(0,70) \\
\end{array}$ & $\begin{array}{c}-0,23 \\
-(0,47) \\
\end{array}$ & $\begin{array}{c}0,20 \\
(0,48) \\
\end{array}$ \\
\hline Size & $\begin{array}{c}0,12 \\
(2,42)^{* *}\end{array}$ & $\begin{array}{c}0,12 \\
(4,49)^{* * *}\end{array}$ & $\begin{array}{l}0,06 \\
(1,55) \\
\end{array}$ & $\begin{array}{c}0,12 \\
(2,37)^{* *}\end{array}$ & $\begin{array}{c}0,07 \\
(1,98)^{* *}\end{array}$ \\
\hline Btm & $\begin{array}{c}-0,30 \\
-(5,82)^{* * *}\end{array}$ & $\begin{array}{c}-0,22 \\
-(4,09)^{* * *}\end{array}$ & $\begin{array}{c}-0,43 \\
-(6,06)^{* * *}\end{array}$ & $\begin{array}{c}-0,29 \\
-(8,22)^{* * *}\end{array}$ & $\begin{array}{c}-0,26 \\
-(4,06)^{* * *}\end{array}$ \\
\hline Mom & $\begin{array}{l}0,05 \\
(0,11)\end{array}$ & $\begin{array}{l}-0,87 \\
-(1,55)\end{array}$ & $\begin{array}{c}-0,70 \\
-(1,24)\end{array}$ & $\begin{array}{c}-1,88 \\
-(2,89)^{* * *}\end{array}$ & $\begin{array}{c}-1,52 \\
-(2,53)^{* *}\end{array}$ \\
\hline
\end{tabular}

Megjegyzés: A regressziókban a hozamokat relatív ESG-vel, valamint kontrollváltozókkal magyaráztam, melyek a piaci béta (Beta), piaci méret (Size), könyv szerinti érték és piaci érték hányadosa (Btm) és a momentum (Mom). A táblázatban a koefficiensek idősoros átlaga (x100), valamint zárójelben a hozzá tartozó Newey-West-féle t-statisztika látható. *** 1 százalékon, ** 5 százalékon, * 10 százalékon szignifikáns. 


\begin{tabular}{|c|c|c|c|c|c|}
\hline Változó & 1 & 2 & 3 & 4 & 5 \\
\hline Nagyon alacsony & $\begin{array}{l}-0,0043 \\
-(2,33)^{* *}\end{array}$ & - & - & - & - \\
\hline Alacsony & - & $\begin{array}{l}-0,0043 \\
-(1,83)^{*}\end{array}$ & - & - & - \\
\hline Közepes & - & - & $\begin{array}{l}-0,0020 \\
-(1,05) \\
\end{array}$ & - & - \\
\hline Magas & - & - & - & $\begin{array}{l}-0,0022 \\
-(1,99)^{* *}\end{array}$ & - \\
\hline Nagyon magas & - & - & - & - & $\begin{array}{c}-0,0050 \\
-(2,59)^{* * *} \\
\end{array}$ \\
\hline Beta & $\begin{array}{c}0,01 \\
(0,02) \\
\end{array}$ & $\begin{array}{l}-0,08 \\
-(0,20)\end{array}$ & $\begin{array}{c}0,18 \\
(0,50) \\
\end{array}$ & $\begin{array}{c}0,00 \\
(0,01) \\
\end{array}$ & $\begin{array}{l}0,25 \\
(0,67) \\
\end{array}$ \\
\hline Size & $\begin{array}{c}0,07 \\
(1,53)\end{array}$ & $\begin{array}{c}0,09 \\
(2,35)^{* *}\end{array}$ & $\begin{array}{c}0,12 \\
(2,53)^{* *}\end{array}$ & $\begin{array}{c}0,01 \\
(0,18)\end{array}$ & $\begin{array}{l}0,05 \\
(0,99)\end{array}$ \\
\hline Btm & $\begin{array}{c}-0,29 \\
-(4,95)^{* * *}\end{array}$ & $\begin{array}{c}-0,33 \\
-(4,99) * * *\end{array}$ & $\begin{array}{c}-0,36 \\
-(4,48)^{* * *}\end{array}$ & $\begin{array}{c}-0,21 \\
-(4,92)^{* * *}\end{array}$ & $\begin{array}{c}-0,14 \\
-(2,16)^{* *}\end{array}$ \\
\hline Mom & $\begin{array}{c}0,08 \\
(0,13)\end{array}$ & $\begin{array}{c}0,23 \\
(0,35)\end{array}$ & $\begin{array}{l}-0,90 \\
-(1,47)\end{array}$ & $\begin{array}{l}-0,67 \\
-(1,30)\end{array}$ & $\begin{array}{l}-0,86 \\
-(1,25)\end{array}$ \\
\hline
\end{tabular}

Megjegyzés: A regressziókban a hozamokat relatív ENV-vel, valamint kontrollváltozókkal magyaráztam, melyek a piaci béta (Beta), piaci méret (Size), könyv szerinti érték és piaci érték hányadosa (Btm) és a momentum (Mom). A táblázatban a koefficiensek idősoros átlaga (x100), valamint zárójelben a hozzá tartozó Newey-West-féle t-statisztika látható. *** 1 százalékon, ** 5 százalékon, * 10 százalékon szignifikáns.

Összességében a relatív pontszámok esetében sem kaptam az eddigiektől eltérő eredményeket. Az iparági átlag alapján való csoportosítások esetében a relatív ESG-t vizsgálva, az egyváltozós sorba rendezés alapján történő portfólió képzéskor csak a nagyon magas csoportban volt szignifikáns hozam, míg a relatív ENV esetében éppen a nagyon alacsony csoportban. A hozamok nagy része azonban nem szignifikáns, a néhány szignifikáns hozam a véletlen eredménye is lehet. A FamaMacbeth-regressziók gyenge negatív kapcsolatot mutatnak, elenyésző gazdasági hatással. Ezen eredmények alapján elutasítom a hipotézist, miszerint a nagyobb relatív pontszámmal rendelkező részvények nagyobb hozamot biztosítanak. 


\subsection{Robusztusság, időbeli bontás}

Mivel a pontszámok Halbritter - Dorfleitner (2015) szerint érzékenyek lehetnek az időhorizontra, ezért ebben a fejezetben az eredmények robusztusságát kívánom alátámasztani azzal, hogy az eddig vizsgált idősort megbontom, és közelebbi, rövidebb időtávon is elvégzem az eddigi vizsgálatok fontosabb részeit. Ahogy az ESG egyre elterjedtebbé vált, úgy egyre nagyobb hatással bírhat. Az eddig vizsgált időszakot így megfelezem, és csak a második felére (2013-2019) fókuszálok a továbbiakban, kiszűrve így a 2008-as válság hatását is, mely szintén nagyban befolyásolhatja az eredményeket.

A rövidebb időtávon elvégzett vizsgálatokban az ESG és ENV között nem látható lényegi különbség, ahogy az eddigiek során sem volt megfigyelhető komolyabb eltérés. Így az átláthatóság miatt csak az ESG-re vonatkozó táblázatokat közlöm7. A sorba rendezés esetében, a teljes piacot vizsgálva a fő eredményeken nem változtat az időszak megbontása. Látható ugyan elmozdulás a pozitív hozam felé, ez azonban nem tekinthető szignifikánsnak egyik esetben sem (14. táblázat). Az értéksúlyozás itt sem befolyásolja nagymértékben az eredményeket.

\section{4. táblázat}

ESG, tercilis és decilis alapú sorba rendezés (2013-2019, teljes piac)

\begin{tabular}{|c|c|c|c|c|c|c|}
\hline & \multirow{2}{*}{ Kvantilis } & \multirow{2}{*}{ Átlag-ESG } & \multicolumn{2}{|c|}{$\begin{array}{c}\text { Egyenlően súlyozott } \\
\text { portfólió }\end{array}$} & \multicolumn{2}{|c|}{$\begin{array}{c}\text { Értékkel súlyozott } \\
\text { portfólió }\end{array}$} \\
\hline & & & Átlaghozam & $\begin{array}{l}\text { Newey- } \\
\text { West t }\end{array}$ & Átlaghozam & $\begin{array}{l}\text { Newey- } \\
\text { West t }\end{array}$ \\
\hline \multirow{7}{*}{ ESG } & 1. & 22,45 & $0,89 \%$ & $(2,83)^{* * *}$ & $0,89 \%$ & $(2,84)^{* * *}$ \\
\hline & 2. & 41,42 & $0,92 \%$ & $(3,04)^{* * *}$ & $0,93 \%$ & $(3,05)^{* * *}$ \\
\hline & 3. & 68,81 & $1,00 \%$ & $(3,64)^{* * *}$ & $1,00 \%$ & $(3,69)^{* * *}$ \\
\hline & 3.-1. & - & $0,11 \%$ & $(1,36)$ & $0,11 \%$ & $(1,32)$ \\
\hline & 1. & 15,96 & $0,85 \%$ & $(2,59)^{* * *}$ & $0,86 \%$ & $(2,64) * * *$ \\
\hline & 10. & 79,70 & $0,96 \%$ & $(3,60)^{* * *}$ & $0,96 \%$ & $(3,60)^{* * *}$ \\
\hline & 10.-1. & - & $0,11 \%$ & $(1,07)$ & $0,10 \%$ & $(0,92)$ \\
\hline
\end{tabular}

Megjegyzés: Az 1. portfólióba kerültek a legkisebb, míg a 3. (vagy 10.) portfólióba a legnagyobb ESG-értékkel rendelkező részvények. *** 1 százalékon, ** 5 százalékon, * 10 százalékon szignifikáns.

\footnotetext{
${ }^{7}$ Igény esetén elérhetőek az ENV-re vonatkozó eredmények is.
} 
A Fama-MacBeth-regressziók esetében pozitív előjelű gyenge, de nem szignifikáns kapcsolat látható (15. táblázat). Ez azt mutatja, hogy valóban érezhető különbség a hosszabb és az újabb, rövidebb időszak között, viszont ez utóbbi esetében sem szignifikáns a kapcsolat. Az iparági csoportos vizsgálatok eredménye is konzisztens az eddigiekkel, és ebből is az látható, hogy az időszak megbontása sem befolyásolja a főbb eredményeket (16. táblázat). Csak kis elmozdulás történik a pozitív irányba itt is. Egyik csoport esetében sem látható szignifikáns hozam sem tercilis, sem decilis alapú sorba rendezésnél.

\section{5. táblázat}

ESG és ENV Fama-MacBeth-regresszió (2013-2019, teljes piac)

\begin{tabular}{|c|c|c|}
\hline Változó & 1. & 2. \\
\hline ESG & $\begin{array}{l}0,0016 \\
(1,21)\end{array}$ & - \\
\hline ENV & - & $\begin{array}{c}0,0011 \\
(1,37)\end{array}$ \\
\hline Beta & $\begin{array}{c}0,0088 \\
(0,05)\end{array}$ & $\begin{array}{l}-0,1160 \\
-(0,64)\end{array}$ \\
\hline Size & $\begin{array}{c}0,0928 \\
(2,93)^{* * *}\end{array}$ & $\begin{array}{c}0,0773 \\
(2,44)^{* *}\end{array}$ \\
\hline Btm & $\begin{array}{c}-0,1235 \\
-(3,87)^{* * *}\end{array}$ & $\begin{array}{c}-0,1029 \\
-(3,23)^{* * *}\end{array}$ \\
\hline Mom & $\begin{array}{l}-0,8806 \\
-(1,67)^{*}\end{array}$ & $\begin{array}{l}-0,4815 \\
-(1,21)\end{array}$ \\
\hline
\end{tabular}

Megjegyzés: A regressziókban a hozamokat ESG-vel vagy ENV-vel, valamint kontrollváltozókkal magyaráztam, melyek a piaci béta (Beta), piaci méret (Size), könyv szerinti érték és piaci érték hányadosa (Btm) és a momentum (Mom). A táblázatban a koefficiensek idősoros átlaga (x100), valamint zárójelben a hozzá tartozó Newey-West-féle t-statisztika látható. *** 1 százalékon, ** 5 százalékon, * 10 százalékon szignifikáns. 


\section{6. táblázat}

ESG, tercilis és decilis alapú sorba rendezés (2013-2019, iparági csoportosítás)

\begin{tabular}{|c|c|c|c|c|c|c|}
\hline & \multirow{2}{*}{ Kvantilis } & \multirow{2}{*}{ Átlag-ESG } & \multicolumn{2}{|c|}{$\begin{array}{c}\text { Egyenlően súlyozott } \\
\text { portfólió }\end{array}$} & \multicolumn{2}{|c|}{$\begin{array}{l}\text { Értékkel súlyozott } \\
\text { portfólió }\end{array}$} \\
\hline & & & Átlaghozam & $\begin{array}{l}\text { Newey- } \\
\text { West t }\end{array}$ & Átlaghozam & $\begin{array}{l}\text { Newey- } \\
\text { West t }\end{array}$ \\
\hline \multirow{4}{*}{$\begin{array}{l}\text { Nagyon alacsony }(28, \\
55,58,73,49)\end{array}$} & 1. & 18,81 & $0,54 \%$ & $(1,30)$ & $0,53 \%$ & $(1,29)$ \\
\hline & 2. & 31,92 & $0,65 \%$ & $(2,14)^{* *}$ & $0,66 \%$ & $(2,15)^{* *}$ \\
\hline & 3. & 58,78 & $0,58 \%$ & $(1,45)$ & $0,57 \%$ & $(1,43)$ \\
\hline & 3.-1. & - & $0,04 \%$ & $(0,41)$ & $0,03 \%$ & $(0,35)$ \\
\hline \multirow{4}{*}{$\begin{array}{l}\text { Alacsony }(85,43,37 \text {, } \\
13,79)\end{array}$} & 1. & 21,82 & $0,99 \%$ & $(3,38)^{* * *}$ & $0,99 \%$ & $(3,41)^{* * *}$ \\
\hline & 2. & 38,49 & $1,04 \%$ & $(3,57)^{* * *}$ & $1,04 \%$ & $(3,60)^{* * *}$ \\
\hline & 3. & 64,57 & $1,03 \%$ & $(3,11)^{* * *}$ & $1,04 \%$ & $(3,15)^{* * *}$ \\
\hline & 3.-1. & - & $0,04 \%$ & $(0,51)$ & $0,05 \%$ & $(0,55)$ \\
\hline \multirow{4}{*}{$\begin{array}{l}\text { Közepes }(19,67,52,40 \text {, } \\
61)\end{array}$} & 1. & 23,37 & $1,01 \%$ & $(2,75)^{* * *}$ & $1,01 \%$ & $(2,78)^{* * *}$ \\
\hline & 2. & 43,90 & $0,88 \%$ & $(2,39)^{* *}$ & $0,88 \%$ & $(2,40)^{* *}$ \\
\hline & 3. & 68,96 & $0,90 \%$ & $(2,68)^{* * *}$ & $0,90 \%$ & $(2,71)^{* * *}$ \\
\hline & 3.-1. & - & $-0,10 \%$ & $-(0,64)$ & $-0,11 \%$ & $-(0,68)$ \\
\hline \multirow{4}{*}{$\begin{array}{l}\text { Magas }(64,25,82,70 \text {, } \\
16)\end{array}$} & 1. & 25,84 & $0,91 \%$ & $(3,43)^{* * *}$ & $0,91 \%$ & $(3,41)^{* * *}$ \\
\hline & 2. & 47,98 & $0,93 \%$ & $(3,15)^{* * *}$ & $0,93 \%$ & $(3,17)^{* * *}$ \\
\hline & 3. & 71,94 & $0,98 \%$ & $(4,29) * * *$ & $0,98 \%$ & $(4,41)^{* * *}$ \\
\hline & $3 .-1$ & - & $0,07 \%$ & $(0,65)$ & $0,08 \%$ & $(0,70)$ \\
\hline \multirow{4}{*}{$\begin{array}{l}\text { Nagyon magas }(34,22 \text {, } \\
31,46,76)\end{array}$} & 1. & 30,22 & $1,04 \%$ & $(3,69)^{* * *}$ & $1,03 \%$ & $(3,66)^{* * *}$ \\
\hline & 2. & 56,66 & $1,08 \%$ & $(5,11)^{* * *}$ & $1,08 \%$ & $(5,19) * * *$ \\
\hline & 3. & 78,80 & $1,08 \%$ & $(5,06)^{* * *}$ & $1,08 \%$ & $(5,05)^{* * *}$ \\
\hline & $3 .-1$ & - & $0,04 \%$ & $(0,24)$ & $0,04 \%$ & $(0,26)$ \\
\hline Nagyon alacsony & 10.-1. & - & $0,04 \%$ & $(0,27)$ & $-0,02 \%$ & $-(0,13)$ \\
\hline Alacsony & 10.-1. & - & $0,16 \%$ & $(1,56)$ & $0,16 \%$ & $(1,48)$ \\
\hline Közepes & 10.-1. & - & $-0,08 \%$ & $-(0,29)$ & $-0,07 \%$ & $-(0,26)$ \\
\hline Magas & 10.-1. & - & $-0,04 \%$ & $-(0,24)$ & $-0,06 \%$ & $-(0,38)$ \\
\hline Nagyon magas & $10 .-1$. & - & $-0,13 \%$ & $-(0,51)$ & $-0,16 \%$ & $-(0,58)$ \\
\hline
\end{tabular}

Megjegyzés: Az 1. portfólióba kerültek a legkisebb, míg a 3. (vagy 10.) portfólióba a legnagyobb ESG értékkel rendelkező részvények a csoporton belül. *** 1 százalékon, ** 5 százalékon, * 10 százalékon szignifikáns. 
Az iparági csoportosítással elvégzett Fama-MacBeth-regressziók esetében hasonló mintázat látható, mint a teljes piac esetében a 2013-2019 időszakra (17. táblázat). A korábbi szignifikáns negatív kapcsolat eltűnik, a nagyon alacsony ESG-értékű csoport esetében szignifikáns pozitív koefficiens figyelhető meg. Ennek viszont a gazdasági jelentősége továbbra is elhanyagolható (mérete miatt). Így itt sem látható jelentőséggel bíró pozitív összefüggés az ESG és a várható hozamok között.

17. táblázat

ESG Fama-MacBeth-regresszió (2013-2019, iparági csoportosítás)

\begin{tabular}{|c|c|c|c|c|c|}
\hline Változó & 1 & 2 & 3 & 4 & 5 \\
\hline Nagyon alacsony & $\begin{array}{c}0,0029 \\
(2,29)^{* *}\end{array}$ & - & - & - & - \\
\hline Alacsony & - & $\begin{array}{c}-0,0090 \\
-(0,45)\end{array}$ & - & - & - \\
\hline Közepes & - & - & $\begin{array}{c}-0,0090 \\
-(0,33)\end{array}$ & - & - \\
\hline Magas & - & - & - & $\begin{array}{c}\mathbf{0 , 0 0 0 6} \\
0,04\end{array}$ & - \\
\hline Nagyon magas & - & - & - & - & $\begin{array}{c}0,0037 \\
(0,87)\end{array}$ \\
\hline Beta & $\begin{array}{c}0,31 \\
(0,53)\end{array}$ & $\begin{array}{c}0,15 \\
(0,30)\end{array}$ & $\begin{array}{c}0,30 \\
(0,58)\end{array}$ & $\begin{array}{c}-0,19 \\
-(0,39)\end{array}$ & $\begin{array}{c}0,17 \\
(0,40)\end{array}$ \\
\hline Size & $\begin{array}{c}0,09 \\
(1,98)^{* *}\end{array}$ & $\begin{array}{c}0,10 \\
(3,67)^{* * *}\end{array}$ & $\begin{array}{c}0,05 \\
(1,27)\end{array}$ & $\begin{array}{c}0,10 \\
(1,94)^{*}\end{array}$ & $\begin{array}{c}0,06 \\
(1,62)\end{array}$ \\
\hline Btm & $\begin{array}{c}-0,25 \\
-(4,92)^{* * *}\end{array}$ & $\begin{array}{c}-0,18 \\
-(3,35)^{* * *}\end{array}$ & $\begin{array}{c}-0,35 \\
-(4,96)^{* * *}\end{array}$ & $\begin{array}{c}-0,24 \\
-(6,72)^{* * *}\end{array}$ & $\begin{array}{c}-0,21 \\
-(3,32)^{* * *}\end{array}$ \\
\hline Mom & $\begin{array}{c}0,04 \\
(0,11)\end{array}$ & $\begin{array}{c}-0,71 \\
-(1,57)\end{array}$ & $\begin{array}{c}-0,57 \\
-(1,25)\end{array}$ & $\begin{array}{c}-1,54 \\
-(2,92)^{* * *}\end{array}$ & $\begin{array}{c}-1,24 \\
-(2,55)^{* *}\end{array}$ \\
\hline
\end{tabular}

Megjegyzés: A regressziókban a hozamokat ESG-vel, valamint kontrollváltozókkal magyaráztam, melyek a piaci béta (Beta), piaci méret (Size), könyv szerinti érték és piaci érték hányadosa (Btm) és a momentum (Mom). A táblázatban a koefficiensek idősoros átlaga (x100), valamint zárójelben a hozzátartozó Newey-West-féle t-statisztika látható. *** 1 százalékon, ** 5 százalékon, * 10 százalékon szignifikáns.

Összességében a 2013-2019 időszakban látható némi növekedés az ESG jelentőségében, azonban a hatása így sem tekinthető szignifikánsnak. Feltételezhető, hogy ha az időszakot tovább rövidíteném napjaink felé, akkor még erősödne ez a hatás, azonban nagyon rövid időtáv vizsgálata már nem szerencsés, mert néhány év alapján nem vonhatók le megbízható következtetések. A 2013-2019 időszak vizsgálata tehát megerősíti az eddigieket, a felállított hipotéziseket elutasítom ezen az időtávon is. 


\section{Konklúzió}

Összegezve a vizsgálatok eredményét: az ESG-t a teljes piacon vizsgálva nem szignifikáns a portfólióképzés hozama, a Fama-Macbeth-regresszió pedig gyenge negatív kapcsolatra utal, mely azonban gazdaságilag nem tekinthető szignifikánsnak. Ez alapján a teljes piac tekintetében az ESG-minősítés nem hordoz plusz értéket, és egyelőre nincs beárazva. Az ENV-t hasonlóan, a teljes piacon vizsgálva egyértelműen nem szignifikáns a portfólióképzés hozama, a Fama-Macbeth-regresszió pedig gyenge negatív kapcsolatra utal, aminek gazdasági jelentősége elenyésző. Ez konzisztens az eddigiekkel. Tehát a környezeti komponens sem hordoz magában befektetési többletthozamot és nincs beárazva. Ez alapján elutasítom a hipotézisem, miszerint a felelős és fenntartható szempontokat figyelembe vevő menedzsmenttel rendelkező vállalatokba történő befektetéssel nagyobb profit érhető el, mint az ezeket a szempontokat mellőző cégekkel.

Az ESG-t iparági bontásban vizsgálva a legtöbb iparág esetében nem szignifikáns a portfólióképzés hozama. Kivétel ez alól 4 iparág, ahol szignifikáns negatív kapcsolat látható (textil-, dohány-, vegyes- és autóipar). Közülük egyik sem környezetbarát, és mindegyik szektorban viszonylag alacsony az ESG. A negatív kapcsolat oka lehet, hogy ezekben az iparágakban a profitábilisabb múködést segíti elő a "felelőtlenebb” magatartás. Egyedül a ruházati iparban kaptam szignifikánsan pozitív hozamot, ez lehet valamilyen nagyon speciális iparági sajátosság, vagy ennyi vizsgálat esetében a véletlen múve is. Az ENV-t vizsgálva részletes iparági bontásban a legtöbb iparág esetében nem szignifikáns a portfólióképzés hozama. Ez alól kivétel 7 iparág, ahol szignifikáns negatív kapcsolat látható, ezek a textil-, a dohány-, az autóipar, az elektromos, az olaj-, gáz- és szén-, a diverzifikált és az élelmiszeripar. A negatív kapcsolat oka ebben az esetben is lehet az, hogy ezekben az iparágakban a profitábilisabb múködést segíti elő a kevésbé környezettudatos magatartás, ez a hatás itt még erősebb, mint az ESG esetében. A ruházati iparban ebben az esetben is szignifikáns hozamot hoz a stratégia, ami mindenképpen érdekes eredmény. Mint láttuk, Kumar és társai is arra jutottak, hogy az iparágaknak lehet jelentősége a felelős befektetések értékelésében, így az eredményeim illeszkednek a szakirodalmi eredményekhez, azonban a feltett hipotézist az iparági bontás esetében is elutasítom.

A csoportos vizsgálatoknál sem az ESG, sem az ENV tekintetében egyetlen esetben sem kaptam szignifikáns hozamot, a Fama-Macbeth-regresszió pedig gyenge negatív kapcsolatra utalt, amely a szélső csoportokban ugyan erősebb, de még ott sem jelentős: a pontszám szerinti ilyen csoportosítás nem különbözik lényegesen a teljes piac vizsgálatától.

A tesztek alapján a szélső értékekre érzékeny lehet a piac, ennek vizsgálatára a relatív ESG-t és relatív ENV-t használtam. A relatív ESG-t és ENV-t sorba rendezéssel vizsgálva a teljes piacon (a „sima” mutatókhoz hasonlóan) egyetlen esetben sem 
szignifikáns. A Fama-Macbeth-regresszió esetében az eddigihez hasonló gyenge negatív kapcsolat látható, mely gazdasági szempontból jelentéktelen. Az 5 csoportra osztott iparági vizsgálat esetén a relatív ESG-re csupán a decilis alapú sorba rendezéskor a nagyon magas csoportnál lett szignifikáns a hozam, és az is csak 10 százalékos szignifikanciaszinten. Érdekes, hogy a relatív ENV-t vizsgálva a nagyon alacsony csoport esetében kaptam szignifikáns hozamot mind tercilis, mind decilis beosztásnál. A Fama-Macbeth-regressziók is valamelyest utalnak erre, ahol a szélső csoportok esetében valamivel erősebb kapcsolatot találtam, azonban ezek az eredmények nem mondhatók robusztusnak, és csak magas szignifikanciaszinten fogadhatjuk el, ennyi vizsgálat esetében pedig ez a véletlen múve is lehet. mindezek alapján elutasítom a hipotézisemet, hogy a profit növelhető, ha különböző szúkítéseket vagy relatív pontszámokat alkalmazok.

A vizsgálat érzékenysége és az eredmények robusztusságának megerősítése miatt egy szúkített időintervallumon (2013-2019) is elvégeztem a jelentősebb vizsgálatokat. Ebben az esetben is hasonló mechanizmus látható, mint a teljes időszakot vizsgálva. Az eredmények valamelyest elmozdulnak a pozitív kapcsolat irányába, de nem szignifikánsak. Ezek alapján az újabb időszak esetében sem tekinthető az ESG-, illetve az ENV-faktor szignifikáns előrejelzőnek a várható hozamokra. Így a felelős és fenntartható befektetésektől egyelőre nem várhatunk nagyobb profitot. A látható elmozdulás a pozitív irányba érdekes kérdéseket vet fel azzal kapcsolatban, hogy napjainkban egyre nőhet a jelentősége a felelős és fenntartható menedzsmentnek, egyelőre azonban ez hosszabb időtávon még nem mutatható ki, azonban a továbbiakban mindenképpen érdekes kutatási területként jöhet számításba.

A néhány helyen tapasztalt negatív kapcsolat feltehetően a felelős és fenntartható menedzsment költségeinek tudható be. Ez kevésbé profitábilis múködést eredményezhet, ami magyarázhatja az enyhe negatív kapcsolatot. A vizsgálatok során a környezeti komponens önmagában lényegében nem tér el a teljes ESG-től. Ez azt jelenti, hogy a környezetvédelmi szempontok nem bírnak kiemelt jelentőséggel. Eredményeim szerint a felelős és fenntartható befektetés nem képes önmagában magasabb profit teremtésére még speciális megkötések mellett sem. Ennek egyik magyarázata a „Greenwashing” jelenség lehet, azaz hogy a szennyező és nem fenntartható vállalatok megpróbálják magukat jó színben feltüntetni és így magasabb ESG-pontszámot elérni. További kutatási irány lehet a Greenwashing pontos hatásának vizsgálata. A további vizsgálatok során érdemes összehasonlítani e tekintetben a fejlett és fejlődő országok piacait. Az eredményeim azt is mutatják, hogy a magas ESG- vagy ENV-pontszámmal rendelkező vállalatok részvényei nem teljesítenek szignifikánsan rosszabbul, mint az alacsony pontszámmal rendelkezők. Ez felveti a további kutatás lehetőségét arra vonatkozóan, hogy milyen kockázat társul ezekhez a hozamokhoz, és vajon a felelős és fenntartható menedzsment csökkentheti-e a kockázatot azonos hozam mellett. Tanulmányom e további kutatási irányok alapját teremtheti meg azzal, hogy részletesen alátámasztja, hogy a felelős és fenntartható menedzsment nem eredményez szignifikánsan magasabb hozamot a befektetők számára. 


\section{Felhasznált irodalom}

Amihud, Y. (2002): Illiquidity and stock returns: cross-section and time-series effects. Journal of Financial Markets, 5(1): 31-56. https://doi.org/10.1016/S1386-4181(01)00024-6

Aouadi, A. - Marsat, S. (2018): Do ESG controversies matter for firm value? Evidence from international data. Journal of Business Ethics, 151(4): 1027-1047. https://doi.org/10.1007/ s10551-016-3213-8

Auer, B.R. - Schuhmacher, F. (2016): Do socially (ir)responsible investments pay? New evidence from international ESG data. The Quarterly Review of Economics and Finance, 59 (February): 51-62. https://doi.org/10.1016/j.qref.2015.07.002

Bakó Barna - Neszveda Gábor - Dezső Linda (2018): When irrelevant alternatives do matter. The effect of focusing on loan decisions. Theory and Decision, 84(1): 123-141. https://doi. org/10.1007/s11238-017-9641-9

Bakó Barna - Neszveda Gábor (2020): The Achilles' heel of Salience theory and a way to fix it. Economics Letters, 193, 109265. https://doi.org/10.1016/j.econlet.2020.109265

Bank Dénes (2018): Implicit és explicit, valamint belső és külső CSR egy kettős függésben lévő piacgazdaságban. Különös tekintettel a munkavállalókról való gondoskodásra = Implicit and explicit, internal and external CSR in a double dependent market economy. Especially regarding labor provisions. Doctoral dissertation, Budapesti Corvinus Egyetem. https:// doi.org/10.14267/phd.2018009

Berlinger Edina - Walter György (1999): Faktormodellek az értékpapírpiacon. Bankszemle, 43(4): 34-43.

Bordalo, P. - Gennaioli, N. - Shleifer, A. (2013): Salience and consumer choice. Journal of Political Economy, 121(5): 803-843. https://doi.org/10.1086/673885

Bóta Gábor (2014): A magyarországi befektetési alapok teljesitményét meghatározó tényezők vizsgálata. Hitelintézeti Szemle, 13(2): 147-163. http://epa.oszk.hu/02700/02722/00071/ pdf/EPA02722_hitelintezeti_szemle_2014_2_147-163.pdf

Buallay, A. (2019), Is sustainability reporting (ESG) associated with performance? Evidence from the European banking sector. Management of Environmental Quality: An International Journal, 30(1): 98-115. https://doi.org/10.1108/MEQ-12-2017-0149

Cao, J. - Titman, S. - Zhan, X. - Zhang, W.E. (2020): ESG Preference, Institutional Trading, and Stock Return Patterns. Working Paper, National Bureau of Economic Research. https:// doi.org/10.3386/w28156

Carhart, M.M. (1997): On persistence in mutual fund performance. The Journal of Finance, 52(1): 57-82. https://doi.org/10.1111/j.1540-6261.1997.tb03808.x 
Csillag Balázs - Neszveda Gábor (2020): A gazdasági várakozások hatása a tőzsdei momentumstratégiára. Közgazdasági Szemle, 67(11): 1093-1111. http://doi.org/10.18414/ KSZ.2020.11.1093

Deák Zsuzsanna - Hajdu Istvánné (2011): Az élelmiszer-ipari vállalkozások környezeti teljesítménye és a pénzügyi eredmények. Gazdálkodás: Scientific Journal on Agricultural Economics, 55(7): 662-667. https://doi.org/10.22004/ag.econ.119945

Dorfleitner, G. - Halbritter, G. - Nguyen, M. (2015): Measuring the level and risk of corporate responsibility - An empirical comparison of different ESG rating approaches. Journal of Asset Management, 16(7): 450-466. https://doi.org/10.1057/jam.2015.31

Fain Máté - Naffa Helena (2019): Aktiv befektetési stratégiák teljesítményének mérése tiszta faktorportfóliókkal. Hitelintézeti Szemle, 18(2): 52-87. http://doi.org/10.25201/ HSZ.18.2.5287

Fama, E.F. - French, K.R. (1992): The cross-section of expected stock returns. The Journal of Finance, 47(2): 427-465. https://doi.org/10.1111/j.1540-6261.1992.tb04398.x

Fama, E.F. - French, K.R. (1996): The CAPM is wanted, dead or alive. The Journal of Finance, 51(5): 1947-1958. https://doi.org/10.1111/j.1540-6261.1996.tb05233.x

Fama, E.F. - French, K.R. (2018): Choosing factors. Journal of Financial Economics, 128(2): 234-252. https://doi.org/10.1016/j.jfineco.2018.02.012

Fama, E.F. - MacBeth, J.D. (1973): Risk, return, and equilibrium: Empirical tests. Journal of Political Economy, 81(3): 607-636.

Fernandez, P. (2015): CAPM: an absurd model. Business Valuation Review, 34(1): 4-23. https://doi.org/10.5791/0882-2875-34.1.4

Gillan, S. - Hartzell, J. - Koch, A. - Starks, L.T. (2010): Firms' environmental, social and governance (ESG) choices, performance and managerial motivation. Unpublished working paper, Texas Tech University and University of Texas at Austin. http://www.pitt. edu/ awkoch/ESG\%20Nov\%202010.pdf. Letöltés ideje: 2020. szeptember 15.

Gloßner, S. (2017): ESG Risks and the Cross-Section of Stock Returns. Finance Meeting EUROFIDAI-AFFI, Paris, December. http://dx.doi.org/10.2139/ssrn.2980917

Golovics József (2015): Korlátozott racionalitás és altruizmus: behaviorizmus a közgazdaságtudományban. Hitelintézeti Szemle, 14(2): 158-172. https://hitelintezetiszemle.mnb.hu/ letoltes/6-golovics.pdf

Halbritter, G. - Dorfleitner, G. (2015): The wages of social responsibility-where are they? A critical review of ESG investing. Review of Financial Economics, 26(1): 25-35. https:// doi.org/10.1016/j.rfe.2015.03.004 
Halldórsdóttir, T.R. (2020) Did firms with higher ESG ranking provide better stock performance during Covid-19? Doctoral dissertation, Reykjavik University. https://skemman.is/ handle/1946/37170?locale=en

Hassel, L.G. - Semenova, N. (2013): The Added Value of Environmental, Social and Governance Performance and Sustainable and Responsible Investment on Company and Portfolio Levels - What Can We Learn from Research? Working paper, Sustainable Investment Research Platform. https://www.researchgate.net/profile/Natalia-Semenova-2/publication/259452763_The_Added_Value_of_Environmental_Social_and_Governance_Performance_and_Sustainable_and_Responsible_Investment_on_Company_and_Portfolio_Levels_-_What_Can_We_Learn_from_Research/links/54bac5a20cf253b50e2d0608/ The-Added-Value-of-Environmental-Social-and-Governance-Performance-and-Sustainable-and-Responsible-Investment-on-Company-and-Portfolio-Levels-What-Can-We-Learnfrom-Research.pdf

Henke, H.M. (2016): The effect of social screening on bond mutual fund performance. Journal of Banking \& Finance, 67(June): 69-84. https://doi.org/10.1016/j.jbankfin.2016.01.010

Ince, O.S. - Porter, R.B. (2006): Individual equity return data from Thomson Datastream: Handle with care! Journal of Financial Research, 29(4): 463-479. https://doi.org/10.1111/ j.1475-6803.2006.00189.x

Jain, M. - Sharma, G.D. - Srivastava, M. (2019): Can Sustainable Investment Yield Better Financial Returns: A Comparative Study of ESG Indices and MSCI Indices. Risks, 7(1), 15. https://doi.org/10.3390/risks7010015

Khan, M. (2019): Corporate Governance, ESG, and Stock Returns around the World. Financial Analysts Journal, 75(4): 103-123. https://doi.org/10.1080/0015198X.2019.1654299

Kotsantonis, S. - Pinney, C. - Serafeim, G. (2016): ESG integration in investment management: Myths and realities. Journal of Applied Corporate Finance, 28(2): 10-16. https://doi. org/10.1111/jacf.12169

Kotsantonis, S. - Serafeim, G. (2019): Four Things No One Will Tell You About ESG Data. Journal of Applied Corporate Finance, 31(2): 50-58. https://doi.org/10.1111/jacf.12346

Kőszegi, B. - Szeidl, A. (2013): A Model of Focusing in Economic Choice. Quarterly Journal of Economics, 128(1): 53-104. https://doi.org/10.1093/qje/qjs049

Kumar, A. - Smith, C. - Badis, L. - Wang, N. - Ambrosy, P. - Tavares, R. (2016): ESG factors and risk-adjusted performance: a new quantitative model. Journal of Sustainable Finance \& Investment, 6(4): 292-300. https://doi.org/10.1080/20430795.2016.1234909

Kumar, R. (2019): ESG: Alpha or Duty? The Journal of Index Investing, 9(4): 58-66. https:// doi.org/10.3905/jii.2019.1.066 
Kuzmina, J. - Lindemane, M. (2017): ESG Investing: New Challenges and New Opportunities. Journal of Business Management, 5(14): 85-98

Lai, T.Y. - Stohs, M.H. (2015): Yes, CAPM is dead. International Journal of Business, 20(2): 144-158.

Landi, G. - Sciarelli, M. (2019): Towards a more ethical market: the impact of ESG rating on corporate financial performance. Social Responsibility Journal, 15(1): 11-27. https://doi. org/10.1108/SRJ-11-2017-0254

Li, F. - Polychronopoulos, A. (2020): What a difference an ESG ratings provider makes! Working Paper. https://www.researchaffiliates.com/en_us/publications/articles/what-adifference-an-esg-ratings-provider-makes.html. Letöltés ideje: 2021. január 17.

Maiti, M. (2020): Is ESG the succeeding risk factor? Journal of Sustainable Finance \& Investment. https://doi.org/10.1080/20430795.2020.1723380

Mérő Balázs - Nagy Olivér - Neszveda Gábor (2019): Új faktorok tesztelése az empirikus eszközárazásban. SZIGMA Matematikai-közgazdasági folyóirat, 50(4): 263-281.

Németh-Durkó Emilia (2019): Környezet és pénzügyek. Budapesti Corvinus Egyetem, Working Paper. http://unipub.lib.uni-corvinus.hu/4294/1/NDE_kornyezet_es_penzugyek.pdf. Letöltés Ideje: 2020. augusztus 18.

Neszveda Gábor (2018): Thaler viselkedési közgazdaságtani munkássága. Hitelintézeti Szemle, 17(1): 153-167. http://doi.org/10.25201/HSZ.17.1.153167

Newey, W.K. - West, K.D. (1987): Hypothesis Testing with Efficient Method of Moments Estimation. International Economic Review, 28(3): 777-787. https://doi. org $/ 10.2307 / 2526578$

Ransburg Beatrix - Vágási Mária (2011): A fenntartható fejlődés vállalati integrációja és kommunikációja - a hazai nagyvállalati gyakorlat vizsgálata. Vezetéstudomány - Budapest Management Review, 42(10): 2-13. https://doi.org/10.14267/VEZTUD.2011.10.01

Ribando, J.M. - Bonne, G. (2010): A new quality factor: Finding alpha with ASSET4 ESG data. Starmine Research Note, Thomson Reuters, 31 March. https://www.thomsonreuters.com/ content/dam/openweb/documents/pdf/tr-com-financial/report/starmine-quant-researchnote-on-asset4-data.pdf

Sahut, J.M. - Pasquini-Descomps, H. (2015): ESG Impact on Market Performance of Firms: International Evidence. Management International/International Management/Gestiòn Internacional, 19(2): 40-63. https://doi.org/10.7202/1030386ar

Shumway, T. (1997): The Delisting Bias in CRSP Data. The Journal of Finance, 52(1): 327-340. https://doi.org/10.1111/j.1540-6261.1997.tb03818.x 
Talan, G. - Sharma, G.D. (2019): Doing Well by Doing Good: A Systematic Review and Research Agenda for Sustainable Investment. Sustainability, 11(2), 353. https://doi. org/10.3390/su11020353

Torre, M.L. - Mango, F. - Cafaro, A. - Leo, S. (2020): Does the ESG Index Affect Stock Return? Evidence from the Eurostoxx50. Sustainability, 12(16), 6387. https://doi.org/10.3390/ su12166387

Townsend, B. (2020): From SRI to ESG: The Origins of Socially Responsible and Sustainable Investing. The Journal of Impact and ESG Investing, 1(1): 10-25. https://doi.org/10.3905/ jesg.2020.1.1.010

US SIF Foundation (2018): Report on US Sustainable, Responsible and Impact Investing Trends 2018. US SIF Foundation study. https://www.ussif.org/files/Trends/Trends\%202018\%20 executive\%20summary\%20FINAL.pdf

Uyar, A. - Karaman, A.S. - Kilic, M. (2020): Is corporate social responsibility reporting a tool of signaling or greenwashing? Evidence from the worldwide logistics sector. Journal of Cleaner Production, 253(April), 119997. https://doi.org/10.1016/j.jclepro.2020.119997

Van Duuren, E. - Plantinga, A. - Scholtens, B. (2016): ESG Integration and the Investment Management Process: Fundamental Investing Reinvented. Journal of Business Ethics, 138(3): 525-533. https://doi.org/10.1007/s10551-015-2610-8

Verheyden, T. - Eccles, R.G. - Feiner, A. (2016): ESG for all? The impact of ESG screening on return, risk, and diversification. Journal of Applied Corporate Finance, 28(2): 47-55. https://doi.org/10.1111/jacf.12174

Wimmer, M. (2013): ESG-persistence in Socially Responsible Mutual Funds. Journal of Management. \& Sustainability, 3(1): 9-15. http://dx.doi.org/10.5539/jms.v3n1p9

Yu, E.P.Y. - Van Luu, B. - Chen, C.H. (2020): Greenwashing in environmental, social and governance disclosures. Research in International Business and Finance, 52(April): 101192. https://doi.org/10.1016/j.ribaf.2020.101192 